\title{
As California goes, so goes the nation? The impact of board gender quotas on firm performance and the director labor market*
}

\author{
Felix von Meyerinck ${ }^{\dagger}$ Alexandra Niessen-Ruenzi ${ }^{\ddagger}$ \\ Markus Schmid $\$$, Steven Davidoff Solomon"
}

December 19, 2018

\begin{abstract}
On September 30, 2018, California became the first U.S. state to introduce a mandatory board gender quota applicable to all firms headquartered in the state. Using a large sample of publicly-listed firms headquartered in the U.S., we find that the introduction of the quota is associated with significantly negative announcement returns to California-headquartered firms. Consistent with the quota imposing frictions, this effect is larger for firms requiring more female directors to comply with the quota. There is also evidence of spillover effects to non-California-headquartered firms. We find evidence in support of two channels through which these spillover effects operate: First, we find spillover effects to be larger for firms operating in industries in which California-headquartered firms lack more female directors to comply with the quota, suggesting that non-California-headquartered firms may lose valuable female directors to California-headquartered firms. Second, we document negative spillover effects for firms headquartered in states dominated by the Democratic Party, consistent with the idea that these firms are more likely to become subject to a board gender quota as well. Finally, we show that, already as of month-end November, female representation on the boards of California-headquartered firms increased. Newly appointed female directors differ significantly in terms of age, independence, and experience from incumbent and leaving female and male directors.
\end{abstract}

JEL Classifications: G14, G34, G38, J23

Keywords: Board Gender Quota, Firm Value, Director Labor Market

${ }^{*}$ We are grateful to Yakov Amihud and seminar participants at Ludwigs-Maximilians-University in Munich and Norwegian University of Science and Technology in Trondheim for helpful comments and discussions. Financial support from the Basic Research Fund of the University of St. Gallen is gratefully acknowledged.

${ }^{\dagger}$ School of Finance, University of St. Gallen, Unterer Graben 21, CH-9000 St. Gallen, Switzerland.

${ }^{\ddagger}$ Department of Finance, University of Mannheim, L9 1-2, D-68131 Mannheim, Germany.

${ }^{\S}$ School of Finance, University of St. Gallen, Unterer Graben 21, CH-9000 St. Gallen, Switzerland.

`Corresponding author: Tel.: + 41 (0) 71-224-7042; E-mail: markus.schmid@unisg.ch.

"Berkeley School of Law, University of California Berkeley, 693 Simon Hall, Berkeley, CA 94720, USA. 


\section{Introduction}

Women are still heavily underrepresented in leadership positions in the U.S. corporate sector. According to Corporate Women Directors International (CWDI) 2018 report, women hold $21.4 \%$ of director positions on the boards of the Fortune Global 200 companies. $19.5 \%$ of these companies have no female directors on their boards. In a country comparison, the U.S. places fifth in 2018 with $26.3 \%$ female directors. This number is surprisingly low, given that women in the U.S. account for about half of the employed population (Bertrand, Black, Jensen, and Lleras-Muney, 2018). Furthermore, the fraction of female directors in the U.S. is growing slowly, at an average rate of $0.5 \%$ annually. If no proactive measures are taken and the current rate of growth remains unchanged, it would take 48 years to achieve gender parity at U.S. boards.

In other countries with similar disparities, legislatures have responded to similar gender inequality by adopting mandatory board quotas. The first country to act was Norway, which introduced a gender quota of 40\% female representation in 2003. Following Norway's lead, Belgium, France, Germany, Iceland, India, Israel, Italy, and Spain have all established similar quotas. These quotas vary in the fraction of women to be appointed, the set of firms that are subject to the quota, and the defined penalty for non-compliance.

In the U.S., California is the first state to adopt a mandatory gender quota. On September 30, 2018, Governor Brown signed Senate Bill 826 into law. SB 826 requires that all national and foreign companies headquartered in California have at least one female director on their board by the end of 2019. Two female directors must be appointed to boards with five members, and three female directors must be be appointed to boards with six members or more by the end of 2021. The statute is non-criminal, but penalties include a payment of $\$ 100,000$ for the first violation, and $\$ 300,000$ for each subsequent violation. It is still an open question whether the quota is illegal as it may conflict with the corporate 
internal affairs doctrine as well as California and U.S. federal civil rights laws.1

The effect of gender quotas on firm performance, board structure and even their effects on gender equality are uncertain. While, in theory, board quotas can be an effective tool to improve gender equality, particularly if gender discrimination is the main obstacle for women to climb the corporate ladder (Bertrand, Black, Jensen, and Lleras-Muney, forthcoming), quotas have also been shown to lead to appointments of younger and less experienced women to corporate boards with adverse effects on firm performance (Ahern and Dittmar, 2012). The latter may result in a stigma put on so called "quota women", such that qualified women may still be reluctant to climb the corporate ladder even if quotas would help them to push through. Moreover, Bertrand, Black, Jensen, and LlerasMuney (forthcoming, p. 1) find that seven years after the Norwegian quota fully came into effect, "it had very little discernible impact on women in business beyond its direct effect on the women who made it into boardrooms."

This paper uses the passage of the California law to investigate a number of questions related to the effect of gender quotas and passage of mandatory social laws applicable to corporations. The first question we explore is how the introduction of a mandatory gender quota affects valuation of California firms. We compute abnormal stock returns for firms headquartered in California and a matched group of control firms for different event windows surrounding the day of the gender quota law's adoption and announcement in California. We observe a robust and significantly negative valuation effect on stock returns of firms affected by the California gender quota. Specifically, firms headquartered in California have a $0.47 \%$ lower announcement return on the first day after the quota announcement than a group of control firms matched on size and industry. This effect is

\footnotetext{
${ }^{1}$ The internal affairs doctrine mandates that matters involving corporate boards are subject to the laws of the state of incorporation, not where the headquarters are located. By targeting all firms headquartered in California, the law deviates from the internal affairs doctrine. Moreover, Senate Bill 826 prioritizes one gender over the other as well as gender over other aspects of diversity. Hence, the law may violate, among others, civil rights laws.
} 
larger for firms requiring more female directors to comply with the quota and for firms with low corporate governance standards. The results are consistent with the theory that smaller firms and firms with inferior corporate governance could face more significant obstacles to recruiting qualified women candidates. Our results are robust to changing the matching procedure and they increase in economic magnitude for larger event windows.

In order to further examine the law and the implications of gender quotas, we examine whether there are spillover effects to firms that are headquartered in states that are likely to follow California. In recent years, California has frequently been the first State to enact progressive legislation that was later adopted by other states in the U.S. as well. For example, California pioneered legislation to promote reductions of carbon emissions from road vehicles introducing a federal waiver to set its own emissions standards, along with a zero-emission vehicle mandate. Thirteen states subsequently adopted California's stricter emissions standards 2 Other examples of California leadership involve renewable energy, sentencing reform, and legalization of marijuana usage. It is reasonable to assume that California's actions on a mandatory gender quota may increase the likelihood that certain other states will follow.

We adopt multiple strategies to examine the spillover effects on firms that are not headquartered in California. First, we examine firms headquartered in democratic states, which are arguably more likely to follow Californian legislation than republican states. We find a negative, albeit weaker, valuation effect on firms in these democratic states, a finding which can be interpreted as investors assessing a higher likelihood of mandatory gender quotas being enacted in these states. In contrast, there is no negative market reaction to the introduction of the gender quota for firms headquartered in republican states. We also examine firms that operate in industries in which Californian firms need to appoint a

\footnotetext{
${ }^{2}$ Known as the "Section 177" states, those 13 states are: Connecticut, Delaware, Maine, Maryland, Massachusetts, New Jersey, New Mexico, New York, Oregon, Pennsylvania, Rhode Island, Vermont, and Washington. See https://mde.maryland.gov/programs/air/mobilesources/pages/states.aspx.
} 
large number of female directors to comply with the quota. We also find negative spillover effects on these firms, a finding which supports the arguments that the gender quota is value-reducing because it increases the competition for scarce, experienced directors.

Finally, we examine whether the board composition of California headquartered firms has changed in response to the new gender quota. We observe that, relative to control firms, there are more women appointed to the boards of firms headquartered in California. Compared to month-end September 2018, California-headquartered firms significantly increased female board representation by 0.36 percentage points two months after the introduction of the quota law (i.e., as of month-end November). Californian firms that are under more pressure to fulfill the quota, i.e., those that require one (two) female director(s) to comply with the quota, have reacted more quickly to appoint female directors than a sample of control firms headquartered in other states. On average, these firms increased female board representation by $0.50(0.55)$ percentage points two months after the introduction of the quota. Some preliminary evidence on the skill set and experience of the newly appointed female directors indicates that they are younger, significantly less likely to possess industry experience or experience as (an outside) director of another listed firm and less likely to be independent than incumbent female and male directors.

Previous evidence on the valuation impact of mandatory gender quotas is ambiguous. While Ahern and Dittmar (2012) document a significantly negative drop in the stock price of firms affected by the introduction of a gender quota in Norway, Eckbo, Nygaard and Thorburn (2018) suggest a value-neutral effect of the Norwegian gender quota on affected firms. The reason for these differing results may be that it is very difficult to establish a proper control group to which affected firms in Norway could be compared (Ferreira, 2015). As all public limited liability firms (i.e., ASA firms) in Norway were affected by the gender quota, control firms would have to be defined as either private firms (that are structurally very different from ASA firms), or firms from neighboring countries or the 
U.S. We circumvent this problem by examining the impact of a gender quota within one country, i.e., the U.S. where only firms in one state are affected by the quota, while all other firms headquartered in different states can potentially serve as control observations.

Our results are in line with Ahern and Dittmar (2012) in that they show a significantly negative short-term valuation effect of the mandatory gender quota. This finding is subject to varying interpretations. One is directly related to the gender quota itself. The value reductions we find may be attributable to investor assessment that the law will lead to the appointment of less-qualified directors and subsequent firm underperformance. In our tests we find evidence that this is the case, finding spillover effects in industries where competition for directors is likely to be more intense and that firms reacting to the law are appointing younger and less experienced directors to corporate boards.

On the other hand, the strong negative valuation results we find are somewhat surprising in that the law only requires the appointment of additional directors not the removal of male directors. Another way to phrase this is that it is surprising that the simple addition of one to three directors would change firm value so substantially. A second interpretation of the results more in line with this skepticism is that the investor reaction is related to an assessment of the willingness of California (and other similarly politically aligned states) to impose non-economic legislation on firms headquartered in that state. Our results on the effect of this law on smaller firms and those with low corporate governance standards imply that firms which might be most affected by future legislation are impacted and also give credence to this hypothesis. However, our findings on spillover effects highlight that the gender quota itself has had some effect and that perhaps both hypotheses are at work here.

Under either hypothesis, our findings suggest that non-economic laws with respect to the corporation have economic effects. In the case of gender equality, studies have found that proactive measures to increase female representation on all management levels within 
a firm seem to be crucial to achieve a sustainable increase of the fraction of women in leadership. $3^{3}$ Gender quotas at the board level do not find this evidential support and appear to be beneficial only to those women that are directly promoted to a board seat due to the quota, but not to all other women in business who were not appointed to boards (Bertrand, Black, Jensen, and Lleras-Muney, 2018).

\section{The gender quota in California: Senate Bill 826}

The Norway gender quota was introduced in 2003 and was followed by similar legislation in other countries, primarily in Europe. For example, Germany, France, and Italy established minimum gender quotas of up to 40 percent (see Table 1). In many of these countries, the adoption of mandatory quotas was preceded by precatory resolutions which called for companies to voluntarily increase female board representation.

In September 2013, California Senate Concurrent Resolution 62 was passed by both houses of the California state legislature. This resolution was non-binding and called for "every publicly held corporation in California with 9 or more director seats have a minimum of 3 women on its board, every publicly held corporation in California with 5 to 8 director seats have a minimum of 2 women on its board, and every publicly held corporation in California with fewer than 5 director seats have a minimum of one woman on its board." California was the first state in the U.S. to adopt such a non-binding resolution. Legislatures in Illinois (May 2015), Massachusetts (October 2015), Ohio (April 2016), Colorado (March 2017), and Pennsylvania (April 2017) all subsequently passed similar resolutions calling for an increase in the fraction of female directors on corporate boards in their states.

\footnotetext{
${ }^{3}$ For example, slow career progression in the five years after the first childbirth has been shown to be a major obstacle for women in business (Keloharju, Knüpfer, and Tag, 2018). A proactive measure that mitigates this problem is government provided child care which allows women to preserve the value of their human capital in child bearing years and helps them pursue their careers in spite of starting a family (Chaochharia, Ghosh, Niessen-Ruenzi, and Schneider, 2017).
} 
The three-year time frame specified in the California resolution ended on December 31, 2016. On that date approximately $20 \%$ of the firms included in the Russell 3000 Index and headquartered in California complied with the resolution's targeted number of female directors. As of June 2017, among the 446 publicly traded California headquarters firms included in the Russell 3000 index, female directors held 566 (15.5\%) of seats, men held $3,089(84.5 \%)$ of seats, and $117(26 \%)$ firms had no female directors.

Senate Bill 826 was introduced on January 3, 2018 with a stated purpose of addressing the continued deficit in women directors at California publicly traded firms. The bill introduced graduated requirements for women directors applicable to any publicly held domestic or foreign corporation with its principal executive offices, according to the corporation's SEC 10-K form, located in California. 4 The Bill generally requires between 25\% (1 / 4) and 50\% (3/6) of female directors on the board. More specifically, the Bill requires that these California firms have a minimum of one female director on its board by the end of 2019. The Bill also requires that, by the end of calendar year 2021, California companies with five directors be required to have two women directors, and companies with six or more directors are required to have three women directors.

The Bill provides an enforcement mechanism which applies financial penalties to companies which do not comply. For a first violation, a fine of $\$ 100,000$ is imposed; for a second or subsequent violation, the fine is increased to $\$ 300,000$. A violation is defined as a "director seat required by this section to be held by a female, which is not held by a female during at least a portion of a calendar year." The maximum fine imposable under the requirements of the Bill is $\$ 900,000$ per year, the fine imposable for an all male board with six or more directors. While this may be economically insignificant for most public firms, we believe that there will be substantial pressure from institutional shareholders and

\footnotetext{
${ }^{4}$ The Bill defines a Female director as "an individual who self-identifies her gender as a woman, without regard to the individual's designated sex at birth."
} 
other constituencies for boards to comply with the law rather than simply pay the penalty. This pressure would be applied more towards larger companies and those with high institutional ownership. For example, when Twitter had its initial public offering it had no female directors and faced significant criticism; Twitter now has three women directors.5

Senate Bill 826 was introduced into the Senate on January 3, 2018 and had its first hearing on May 7, 2018. The Bill first passed the Senate on May 31, 2018 (23:8:9 votes) and the Assembly on August 29, 2018 (41:13:26 votes), and the Senate passed the amendments made by the Assembly on August 30, 2018 (23:9:8 votes).

The Bill was presented to the Governor's office for signing on September 10, 2018. Governor Brown is known for his "willingness" to veto bills and vetoed 12\% of bills in 2017 and $15 \%$ in 2016 ${ }^{6}$ He did not initially announce what he would do with Senate Bill 826 and news and commentary at the time highlighted that it was uncertain whether he would sign the Bill.7 On Sunday September 30, 2018, SB 826 was signed into law by Governor Brown and announced the same day.

Governor Brown signed the Bill despite significant commentary that it could be unconstitutional (Grundfest, 2018). California's own legislative analysis concludes that "the use of a quota-like system, as proposed by this bill ... may be difficult to defend." The argument for unconstitutionality has thus far focused on two grounds. First, that the Bill violates the internal affairs doctrine since it purported to regulate firms incorporated in

\footnotetext{
${ }^{5}$ See Claire Cain Miller, Curtain Is Rising on a Tech Premiere With (as Usual) a Mostly Male Cast, The N.Y. Times, Oct 4, 2013.

${ }^{6}$ Angela Hart, Jerry Brown consistently signs more bills than GOP governors, Sacramento Bee, Oct. 17, 2017. See also Tim Arango \& Jose A. Del Real, 5 Takeaways from California Gov. Jerry Brown's Last Bill Signing Session, The N.Y. Times, Oct. 1, 2018 (Governor Brown has a "willingness to wield the veto pen").

7 David Matsa, Norway's quota for women on boards suggests an overlooked benefit - to workers, Quartz, Sept. 28, 2018, available at https://qz.com/work/1406503/if-california-mandates-a-gender-quotafor-company-boards-it-could-be-good-for-workers/ "Governor Brown has not indicated whether he will sign the bill."); Jorge L. Ortiz, Gender quotas: California ponders breakthrough bill to boost female executives, USA Today, Sept. 18, 2018 ("As California Gov. Jerry Brown ponders whether to sign a landmark bill...").
} 
Delaware or another State and headquartered in California. Second, that the imposed quota violates the U.S. and California Constitutional equal rights protections. In his signing statement, Governor Brown stated "there have been numerous objections to this bill and serious legal concerns have been raised." Nonetheless, Governor Brown asserted that "it's high time corporate boards include the people who constitute more than half the 'persons' in America."

\section{Data and sample}

\subsection{Sample selection and data sources}

To compile our sample, we first select all firms in Compustat with a data entry within one calendar year before September-end 2018, the date of the introduction of the gender quota in the state of California. We drop utility and financial firms (SIC codes 4940-4949 and 6000-6999, respectively), firms with missing information on the state in which they are headquartered, firms headquartered outside the US, firms with negative book value of equity, and firms with missing financial control variables as described below. Moreover, we drop firms that only list American Depository Receipts (issue IDs 90 or above) and firms without a listing on NYSE, AMEX, or NASDAQ (stock exchange codes 11, 12, and 14, respectively). This initial sample selection results in a sample of 2,562 firms that enter the sample with the most recent fiscal year-end balance sheet data in Compustat that predates September 30, 2018. 475 firms are headquartered in the state of California and the other 2,087 firms in one of the other 49 US states or the D.C.

To analyze the market reaction to the introduction of the gender quota, we supplement 
our sample with stock return data from Compustat 8 Compustat reports more than one return series for 172 firms (6.7\% of the sample). In these cases, we chose the time-series with the highest market capitalization as of the event date among those return series with sufficient data to run the market model.

Governor Brown signed the law on Sunday, September 30, 2018. On the same day, the adoption of the law was publicly announced. Hence, the first trading day, and thus the event date, is Monday, October 1. We compute daily abnormal returns (ARs) for a symmetric five-day window around the event date. Abnormal returns are computed as the observed return less the predicted return from a market model regression estimated over a 250-day estimation window that ends on Friday, September 21, i.e., six trading days before the event date and four trading days before the start of the event window. As a proxy for the market return, we use the return of a self-computed, value-weighted market index consisting of all sample firms. For a firm to be included in our final sample, we require at least 125 daily return observations during the estimation window and complete return data during the entire five-day event window. We are unable to compute abnormal shareholder value changes around the announcement of the quota's adoption for 100 firms, resulting in a final sample of 2,462 firms, out of which 456 are headquartered in California and 2,006 are headquartered in other states of the US or the D.C.

Additionally, we compute a set of alternative cumulative abnormal returns (CARs) over different sub-periods within the five-day event window. Our base case measure of the market's reaction to the introduction of the gender quota is a two-day event window, which

\footnotetext{
${ }^{8}$ At the time of writing, daily stock return data from the Center for Research in Security Prices (CRSP) are only available through the end of June 2018 and the update schedule provided by the Wharton Research Data Service (WRDS) suggests that daily stock return data from CRSP covering our time-period will not become available until August 2019. Moreover, the CRSP-Compustat matching table necessary to merge CRSP and Compustat is only available through January 2018. In order to analyze whether there are any material differences between CRSP's and Compustat's return data, we compare return observations in January 2018, the one month in our estimation window for which matched data are available from both databases. We find that only 298 out of 43,349 return observations (0.7\%) differ by more than 0.01 percentage points, suggesting that return data in CRSP and Compustat are very similar.
} 
includes the event day (October 1) and the following day (October 2). All abnormal return measures are winsorized at the 1st and 99th percentiles to mitigate the effect of outliers.

Some of our tests require detailed data on the board of directors of our sample firms. We obtain board data from BoardEx. BoardEx includes detailed information on current and past employments, education, involvement in non-profit organizations and club memberships, among other things, on almost all directors serving on boards of publicly listed US firms. BoardEx is updated daily and organizes its data at the director level. This allows us to observe a firm's board structure at any point in time and, thus, to analyze how board structure changes in response to the introduction of a gender quota. Moreover, we can track individual directors over time and across firms. This enables us to construct detailed measures of directors' work experience and to construct measures of directors' connections to other directors or top executives (e.g., Custódio, Ferreira, and Matos, 2013; Engelberg, Gao, and Parsons, 2013).

\subsection{Descriptive statistics}

Panel A of Table 2 reports descriptive statistics for the sample of 2,462 firms. 456 firms $(18.5 \%)$ have their headquarters in California. On average, sample firms have total assets of almost USD 6.4 billion, carry $22.1 \%$ of assets as long-term debt or debt in current liabilities, have $22.0 \%$ of assets invested in property, plant, and equipment, invest $8.4 \%$ of total assets per year in research and development, and achieve a return on assets of $-1.8 \% .9$ As of September 30, our sample firms have a mean (median) board size of 8.1 (8.0), out of

\footnotetext{
${ }^{9}$ The return on assets (ROA), defined as operating income before depreciation and amortization scaled by total assets, is surprisingly low when compared to the median of $8.6 \%$. As ROA is winsorized at the 1st and 99th percentiles, this suggests that the sample is comprised of a substantial number of firms with strongly negative ROA values. In unreported tests, we find this pattern not to be an artifact of our sample selection or variable construction. Specifically, we find similar numbers when computing ROA as net income scaled by total assets (mean: -9.1\%; median: 1.8\%), when using EBITDA scaled by total assets (mean: $-1.8 \%$; median: $8.6 \%$ ), and when winsorizing ROA at the 5th and 95th percentiles (mean: $-0.1 \%$; median: $8.6 \%$ ). Moreover, we find even more negative (winsorized) ROA values when looking at the entire cross-section of Compustat firms (mean: $-31.4 \%$; median: $4.1 \%$ ).
} 
which $15.3 \%(14.3 \%)$ are female directors. The quota imposed on firms headquartered in California mandates that firms have to have, by the end of the calendar year 2021, three female directors if board size is six or more, two female directors if board size is five, and one female director if board size is four or less. Using data on board size and directors' gender, we find that, at the time of the adoption of the quota law, 84.0\% of all firms are not in compliance with the mandated quota that would apply to the current board size (2021 requ. failed $(\mathrm{d}))$. To comply with the quota, firms would have to appoint on average 1.5 (median: 2.0) female directors (\# female directors missing), or, if expressed as a fraction of board size, would have to increase female board representation on average by $21.4 \%$ (median: $22.2 \%$ ) to comply with the gender quota (Shortfall (\%)).

\subsection{Construction of matched control sample}

In most our tests, we compare the reaction to the quota of treated firms, i.e., firms headquartered in California, with the reaction of a sample of control firms, i.e., firms headquartered in the other 49 US states or the D.C. The validity of such tests rests on the assumption that the two groups of firms are comparable before the onset of treatment. Prior research looking at the Norwegian gender quota, which affected all public limited companies (ASA) in Norway, had to resort to private limited liability companies (e.g., Matsa and Miller, 2013; Eckbo, Nygaard, and Thorburn, 2018), listed firms from other Scandinavian countries (e.g., Ahern and Dittmar, 2012; Matsa and Miller, 2013), or listed US firms (e.g., Ahern and Dittmar, 2012) as a control group. Both, foreign and privately held firms, constitute imperfect control groups as they are subject to, for example, different corporate governance (guidelines) and regulation. On top of that, foreign firms even differ in terms of the macroeconomic environment (Ferreira, 2015). A major advantage of our setting is that we can draw control firms from a large pool of listed domestic companies with headquarters in another US state or the D.C. 
To obtain treatment and control groups that are similar in terms of observable financial and in particular board characteristics, we apply alternative matching procedures to define a sample of control firms. Our first matching procedure, which serves as a base case, consists of choosing, for each of our 456 treatment firms headquartered in California, three non-California-headquartered firms that share the same primary two-digit SIC and are closest in terms of total assets. We match with replacement, i.e., a firm in the control sample may serve as a matched control firm to more than one treatment firm, but we include every control firm only once in the sample. The resulting final sample comprises 1,233 firms, 456 in the treatment group and 777 in the control group.

Balancing tests reported in Table OA.1 in the Online Appendix show that this matching procedure indeed results in a control sample that is similar to the treatment sample in terms of board characteristics. Specifically, the results in Panel A, which compares California-headquartered to all non-California-headquartered firms in the full sample, show that California-headquartered firms are not only significantly different from non-Californiaheadquartered firms in terms of financial control variables, but also have smaller boards and require more female directors to comply with the quota requirements. Panel B of Table OA.1 compares California-headquartered firms to the matched control sample. While differences in financial controls are reduced, all but firm size, which is a matching characteristic, remain significant at conventional levels. More importantly, however, differences in board structure and requirements to comply with the quota turn economically and statistically insignificant. To address concerns of differences in financial controls between California-headquartered firms and non-California-headquartered firms, we conduct robustness tests in which we control for these observable financial firm characteristics. Our results hold.

In other robustness tests, we use several alternative matching procedures. For example, we use propensity score matching to identify for each firm in the treatment sample the three 
closest matches from the subsample of non-California-headquartered firms ${ }^{10}$ Alternatively, we only choose the single closest propensity score matched firm, reducing the size of the control sample. We also conduct robustness tests in which, for each firm in the treatment sample, we select one non-California-headquartered firm that shares the same primary twodigit SIC code and is closest in terms of total assets. As in all matching procedures that we employ, we allow one specific control firm to serve as a matched control to more than one treatment firm but include any control firm only once in our sample. Finally, we also conduct robustness tests in which we use all non-California-headquartered firms as control sample. In general, results are very insensitive to the use of alternative control samples.11

\section{The impact of the gender quota on firm peformance}

\subsection{Main results}

To analyze the market reaction to the introduction of the quota, we estimate marketadjusted firm value changes at firms subject to the quota and, in order to control for concurrent effects, compare them to market-adjusted firm value changes at firms not subject to the quota. To this end, we regress different abnormal return measures on a treatment indicator, that is, a dummy variable set equal to one if a firm's headquarters are located in the state of California and zero otherwise. Standard errors are robust and clustered by two-digit SIC code level. The event date is Monday, October 1, 2018, the first trading day after the public announcement of the quota by the Governor's office. The announcement was made on Sunday, September 30, after the Governor had signed the law earlier that day. In our baseline setting, the sample consists of all California-headquartered firms

\footnotetext{
${ }^{10}$ Propensity scores are estimated using the following explanatory variables: ROA, Leverage, $\ln$ (Total assets), PPE / AT, R\&D/AT, and 2-digit SIC code industry dummies.

${ }^{11}$ We have also experimented with the addition of common support constraints by means of a restriction imposed for differences in total asset assets $(+/-50 \%$ of the California-headquartered firm) when using industry-size matching or by adding a caliper restriction (0.01) when using propensity score matching. Applying such restrictions leaves our results virtually unchanged.
} 
that pass the filters described in Section 3.1 and three industry- and-size matched control firms per treatment firm as described in Section 3.3 (with replacement and avoiding double-counting). Daily abnormal returns are computed as the observed return minus the predicted return from a market model regression estimated over a 250-day estimation window that ends on Friday, September 21. As a proxy for the market return, we use the return of a self-computed, value-weighted market index consisting of all sample firms.

Panel A of Table 3 reports the results from such difference-in-differences regressions using six different abnormal return measures, estimated over different event windows that range from one to five days in length. The results in Column 1 show, that the abnormal return on the first trading day after the announcement (i.e., on October 1, 2018) is $0.47 \%$ lower for California-headquartered firms than for the matched control firms. The coefficient on the dummy variable whether the firm is headquartered in California is significant at the $1 \%$ level (t-statistic of -4.00). The results in Column 2 indicate that also on the second trading day after the announcement (October 2), California-headquartered firms significantly underperform the sample of matched control firms by $-0.35 \%$. When we compute cumulative abnormal returns as the sum of the daily returns over the two days following the announcement of the introduction of the gender quota, in Column 3, we find 0.75\% lower returns for California-headquartered firms compared to the sample of matched control firms. The obtained estimate is not only economically relevant but also statistically significant with a t-statistic of -3.49 . These results remain statistically significant and economically meaningful when we extend the event window to a symmetric three-day event window (Column 4), an asymmetric three-day event window (Column 5), or a symmetric five-day event window (Column 6). With $-1.19 \%$, the latter is comparable to Ahern and Dittmar (2012), who report a five-day abnormal stock returns of $-3.54 \%$ for Norwegian firms with no female directors around the quota adoption, compared to $-0.02 \%$ for firms with at least one female director. In California, the five-day announcement effect appears 
to be economically smaller than the effect in Norway. This may have to do with the fact that penalties in Norway are higher (i.e., the firm would be liquidated if it violates the quota requirement) and that there is still uncertainty in California whether the bill is unconstitutional.

The identifying assumption central to a causal interpretation of our difference-in-differences results in Table 3 is that treated and control firms share parallel trends before the onset of treatment, i.e., the introduction of the quota on September 30. Panel A of Figure 2 shows mean daily abnormal returns around the event date for the California-headquartered firms and for size- and industry-matched non-California-headquartered control firms. Panel B shows differences in mean daily abnormal returns between the two groups. In Panel A, the three pre-treatment observations (September 26 to September 28) confirm that the parallel trends assumption is fulfilled as the trends in pre-treatment abnormal returns are indistinguishable between the two groups of firms. On the event day, i.e., the first trading day after the announcement of the introduction of the quota (October 1), and the subsequent day (October 2), however, the abnormal returns of California-headquartered firms are significantly more negative by $-0.47 \%$ and $-0.35 \%$, respectively (t-statistics of -2.37 and -1.90).12 On October 3, the difference in mean abnormal returns shrinks to an insignificant $-0.14 \%$. Panel B of Figure 2 confirms these patterns and again provides supportive evidence for the parallel trends assumption: There is clearly no difference in the pre-treatment trends across the two groups of firms.

In Panel B of Table 3, we test for the robustness of these results with respect to the model used to predict daily expected returns. Instead of applying a regression-based market

\footnotetext{
12 Results from tests for differences in means and tests whether means are significantly different from zero are reported in Table OA.2 in the Online Appendix. The mean abnormal returns of both the group of California-headquartered firms and the group of matched control firms are significantly negative on the first two trading days after the introduction of the quota $(-2.48 \%$ and $-1.73 \%$; t-statistics of -11.63 and -10.11, respectively), suggesting that there may be spillover effects to non-California-headquartered firms or an anticipation of other states introducing quotas as well. We analyze potential spillover effects and channels through which they operate in Section 6 of the paper.
} 
model to predict expected returns in the event window as in Panel A, we rely on a marketadjusted model. That is, we subtract the daily market return from the observed daily stock returns to obtain daily abnormal returns. The market-adjusted model mitigates concerns of misestimated betas and simply assumes that each firm has a beta of one. The results remain qualitatively unchanged, but the economic magnitude of the coefficient estimates is, if anything, slightly reduced. For instance, the average two-day cumulative abnormal return difference between firms headquartered in California and the control firms is now $-0.74 \%$ (Column 3) versus $-0.75 \%$ in Column 3 of Panel A, but still significant at the $1 \%$ level (t-statistic of -3.70).

In Panels $\mathrm{C}$ and $\mathrm{D}$, we vary the control group. In Panel $\mathrm{C}$, we use propensity score matching to identify matched control firms. Specifically, we use profitability (ROA), leverage, firm size, asset structure (PPE / AT), R\&D intensity (R\&D / AT), and 2-digit SIC code industry dummies to estimate propensity scores. We then choose the three closest propensity score matched control firms. As with the size- and industry-matching applied in our baseline setting, a non-California-headquartered firm may serve as a matched control firm to more than one California-headquartered firm, but every control firm is included only once in our control sample. In Panel D, we use all non-California-headquartered firms that pass our sample selection procedure explained in Section 3.1 as control group. The results obtained in both panels are very similar to those reported in Panel A.

Panel E reports results from a set of additional robustness tests. For the sake of brevity, we only report results from tests using the two-day $\operatorname{CAR}(\operatorname{CAR}(0,1))$ as dependent variable. In Columns 1 and 2, we only select the single closest matched control firms in the size- and industry-matching procedure of Panel A and the propensity score matching approach used in Panel C, respectively. The coefficients on the dummy variable whether the firm is headquartered in California are again similar to previous estimates, and, despite substantial reductions in sample size by about one third to 810 and 792 firms, respectively, 
remain significant at the $10 \%$ level or higher. The remaining four tests should mitigate concerns that a small number of observations in our sample may drive the results documented so far. The control sample is obtained using the same size- and industry-matching procedure as in Panels A and B. In Column 3, we test whether penny stocks drive our results and exclude all stocks in our sample with day-end closing prices below USD 1 on the event date from the sample (e.g., Amihud and Stoyanov, 2017). In Columns 4 and 5, we winsorize the cumulative abnormal returns at the 0.5 th and 99.5 th and 5 th and 95th percentiles, respectively, instead of the 1st and 99th percentiles. Finally, in Column 6, we estimate median regressions without winsorization of the dependent variable instead of OLS regressions with winsorization to mitigate the effect of outliers. In all these tests reported in Panel E, we find the results to remain qualitatively similar.

Taken together, the results in Table 3 show that the adoption of the California mandatory gender quota law is associated with negative and significant announcement returns, suggesting that the introduction of the quota imposes significant costs on Californiaheadquartered firms and their shareholders. Economically, the estimates vary but indicate that California-headquartered firms underperform non-California-headquartered control firms by between $-0.53 \%$ and $-1.01 \%$ over a two-day period that includes the two trading days after the announcement. As one would expect, the bulk of the abnormal market reaction occurred on the first trading day after the announcement. The result that California-headquartered firms lost substantial value following the quota's introduction is remarkably robust and remains if we use alternative event window lengths, construct different control groups, or take various measures to mitigate the impact of outliers.

\subsection{Controlling for firm and industry characteristics}

In Columns 1 to 5 of Table 4, we test whether our estimate for the loss in shareholder value around the law's announcement is robust to controlling for a set of firm-level covari- 
ates as well as industry-level effects. If treatment assignment is exogenous, and thus if our difference-in-differences analysis is valid, the inclusion of covariates should not materially affect our results obtained in Table 3 and discussed above. In Column 1 of Table 4, we therefore add a set of firm specific control variables to our baseline specification reported in Panel A of Table 3, Column 3. These variables capture a firm's return on assets, its leverage, its size, the fraction of total assets invested in property, plant and equipment, and the fraction of total assets invested in R\&D expenditures. In Column 2, we additionally add two-digit SIC code industry dummies. These industry fixed effects absorb unobservable industry characteristics, such as industry shocks occurring simultaneously with the announcement of the quota adoption. In Columns 3 to 5, we vary the industry definition underlying the industry dummies: one-digit SIC industries (Column 3), three-digit SIC industries (Column 4), and Fama-French 48 industries (Column 5). Across all these specifications, the coefficient on the dummy indicating whether a firm is headquartered in California remains economically similar to Table 3 and statistically significant at the $10 \%$ level or higher.

\subsection{Alternative event dates}

Our event study results so far focus on the date on which the Governor of California signed the quota law. The quota was introduced on January 3, 2018, passed the California State Senate on May 31, the California State Assembly on August 29, 2018, and the Senate passed the amended version on August 30. Media coverage on the quota was heavily concentrated on the days following the signature of the law by the Governor, suggesting that the quota's adoption announcement represents the most influential event. This is also consistent with press reports at the time which highlighted the governor's uncertain support of the law. However, as Eckbo, Nygaard and Thorburn (2018) point out, it is important to include all major quota-related news events that increase the likelihood of a 
quota law in an analysis of changes in firm value. Therefore, we test whether significant market reactions are also observable at the time of the introduction of the quota law on January 3 or the successful votes on the legislation on May 31, August 29, and August 30. Hence, we conduct a similar difference-in-differences analysis as described in Section 4.1 but use January 1, May 31, and August 29 and August 30 as event dates, respectively. Specifically, in Columns 6 and 7 of Table 4, we estimate cumulative abnormal returns over a two-day event window that includes the introductory date (January 3) and the day after (January 4). In Columns 8 and 9, we estimate cumulative abnormal returns over a two-day event window that includes the vote date (May 31) and the day after (June 1). Finally, in Columns 10 and 11, we use a three-day event window that includes the days of the Assembly and the second Senate votes, which took place on consecutive days (August 29 and 30), and the day after. All four coefficients are positive and statistically insignificant at conventional levels, suggesting that the market reaction to the California gender quota was confined to the days after the Governor signed the law.

\subsection{Standard difference-in-differences estimates}

In this section, we conduct a standard difference-in-differences analysis using a treatment dummy and a post-treatment dummy. To this end, we estimate OLS regressions of daily abnormal returns (ARs) on a dummy variable which is equal to one if a firm is headquartered in California (CA HQ (d)) and zero otherwise, and a dummy variable which is equal to one for observations measured after the implementation of the quota (Post (d)) and zero for observations measured before the implementation of the quota. We also add an interaction term between these two variables. Standard errors are clustered by firm-level. The results are reported in Table 5. Column 1 reports results obtained when using a fourday event window with two pre-treatment and two post-treatment observations per sample firm. Consistent with results reported in Tables 3 and 4, the difference-in-differences es- 
timator, i.e., the coefficient on CA HQ $(d) \times$ Post $(d)$, is negative and significant at the $5 \%$ level. In terms of economic magnitude, the coefficient suggests a two-day abnormal return of California-headquartered firms that is $0.78 \%$ lower than that of non-Californiaheadquartered firms ( $0.39 \%$ per post-treatment day), a number reasonably close to the two-day abnormal return difference of between $-0.53 \%$ and $-1.01 \%$ reported in Table 3 . The results in Columns 2 and 3 show that the inclusion of industry dummies and a set of firm-level control variables and industry dummies, respectively, leaves the results virtually unchanged. In Column 4, we add firm fixed effects to the specification in Column 1 to control for unobservable heterogeneity at the firm-level that is time-invariant. Note that the firm fixed effects absorb all firm-level covariates, including the treatment dummy, CA HQ (d), as these variables are time-invariant over the sample period used in this analysis. While the t-statistic is slightly reduced, the difference-in-differences estimate remains economically unchanged, still suggesting a two-day abnormal return difference of $0.78 \%$ 13

\subsection{Calendar-time portfolio analysis}

In this section, we conduct robustness tests that address concerns arising from the fact that we study the market reaction of firms to one single event date. More specifically, all firms in the treatment group, i.e., the firms headquartered in California in our sample, are treated at the same date, October 1, 2018. Such a single event date may result in contemporaneous cross-correlation of (abnormal) stock returns. To address this concern, we follow Eckbo, Nygaard, and Thorburn (2018) and form equally-weighted calendar time portfolios of all California-headquartered firms, our treatment sample, and all non-California headquartered size- and industry-matched control firms, our control sample. We then estimate the portfolios' daily abnormal returns by estimating the following time-series regression

\footnotetext{
${ }^{13}$ In unreported results, we extend the event window to a six-day period around the announcement of the quota. The difference-in-differences estimator remains statistically significant at the $10 \%$ level and economically comparable to our main results.
} 
over a sample that includes all observations from the 250-day estimation window, which ends on September 21, and the observations from the respective event window:

$$
r_{t}=\alpha+A R d_{t}+\beta r_{w t}+\epsilon_{t}
$$

where $r_{t}$ is the daily equally-weighted return of the portfolio of all California-headquartered (or size- and industry matched control) firms in excess of the daily 1-month US treasury bill rate. Alternatively, to analyze differences in abnormal returns between Californiaheadquartered and non-California-headquartered firms, we define $r_{t}$ as the daily difference in portfolio returns of California-headquartered and non-California-headquartered firms. $r_{w t}$ is the daily value-weighted market index return in excess of the daily 1-month US treasury bill rate. As a proxy for the market return, we use the return of a self-computed, value-weighted market index consisting of all sample firms. $d_{t}$ is a dummy variable that takes a value of one for each day in the event window and zero otherwise. $A R$ is the average daily abnormal portfolio return over the event days. Hence, estimates for the cumulative abnormal returns are obtained by multiplying the obtained coefficient for $A R$ by the number of days in the event window. For instance, to obtain the two-day $\operatorname{CAR}(0,1)$, $d_{t}$ takes a value of one in the two-day event window that includes the first two trading days after the quota came into effect. The two-day cumulative abnormal return, $\operatorname{CAR}(0,1)$, is then computed as $2 \times A R$.

The results are reported in Table 6. As in Table 3, we use six alternative abnormal return measures, estimated over event windows that range from one to five days in length. Consistent with results reported in previous tables and in Figure 2, we find announcement returns to the introduction of the quota to be significantly more negative for Californiaheadquartered firms, as shown in the last two columns of the table. In terms of economic magnitude, the results obtained here are similar to those reported in Table 3. For instance, 
the two-day cumulative abnormal return, which includes the event day and the day after $(\mathrm{CAR}(0,1))$, is $-0.75 \%$ in Panel A of Table 3 and $-0.76 \%$ in Table 6 . Hence, accounting for potential contemporaneous cross-correlation resulting from a single event does not materially affect our results.

\section{Cross-sectional tests}

In this section, we analyze whether all California-headquartered firms are equally affected by the passage of the law or whether there are important cross-sectional differences. For instance, if the quota's introduction is expected to result in supply side frictions on the (female) director labor market, we would expect California-headquartered firms to be more (negatively) affected the fewer female directors they have on the board at the time of the introduction of the quota and the more directors are required to comply with the quota's requirements. Similarly, we would expect larger firms to be less (negatively) affected by the quota as larger firms are generally more attractive employers to directors as both compensation and reputation are strongly positively correlated with firm size.

Following Ahern and Dittmar (2012), we analyze such cross-sectional patterns using pooled OLS regressions of two-day cumulative abnormal returns (CARs) on a dummy variable that is equal to one if a firm is headquartered in California (CA HQ (d)), a firmspecific characteristic, e.g., related to quota compliance or female board representation, and an interaction term between the dummy whether the firm is headquartered in California and the firm characteristic. In other words, we use the regression framework from Column 3 in Panel A of Table 3, and saturate it with a firm-characteristic and an interaction term between a firm-characteristic and the California-headquarter indicator. Results are reported in Tables 7 and 8. In the first column of Table 7, we interact the California-headquarter dummy with a variable equal to one if a firm is, as of September 30, not complying with the quota, and zero otherwise. The results imply that California-headquartered firms not 
in compliance with the quota underperform California-headquartered firms in compliance with the quota by $-1.03 \%$ (significant at the $1 \%$ level). The coefficient on the stand-alone variable indicating whether a firm complies with the quota is insignificant. The stand-alone coefficient on the California-headquarter indicator is positive and significant at the $10 \%$ level, suggesting that California-headquartered firms, that elected female directors early and were in compliance before the introduction of the quota, may even benefit from the introduction of the quota. Next, we analyze whether the market reaction at Californiaheadquartered firms not only depends on whether firms fail to comply with the quota but whether it also depends on the extent to which the quota is not fulfilled. To this end, in Column 2, we use a variable that counts the number of female directors necessary to fulfill the quota (\# female directors missing), and, in Column 3, we use this variable scaled by board size (Shortfall (\%)). Both variables, when interacted with the California headquarter indicator, load significantly negative, suggesting that the market reaction indeed varies with the female director gap on the board of California-headquartered firms. Moreover, the coefficient on the stand-alone California-headquarter indicator variable is indistinguishable from zero once we control for the need of California-headquartered firms to appoint female directors, supporting the notion that stock return differences between firms headquartered in California and their matched peers around the introduction of the quota are not driven by other factors than the female director gap. Rather, these results imply that frictions associated with appointing female directors increase with the number of female directors needed to fulfill the quota.

In Column 4 of Table 7, we test whether the stock market response depends on the percentage of female directors on the board. The results show that California-headquartered firms show a more negative announcement return to the introduction of the quota in general - the standalone coefficient on CA HQ (d) is negative and significant at the $1 \%$ level - but that the announcement return becomes more positive the larger the percentage of female 
directors on the board. Indeed, the interaction term between the California-headquarter indicator and the percentage of female directors on the board is positive and significant. This finding is consistent with the results in Columns 1 to 3.

Besides using this setting to explain variation in the abnormal stock returns around the quota adoption announcement with board structure variables, we are also interested in shedding light on the question which firms face larger difficulties in appointing female directors. In Columns 1 and 2 of Table 8, we study the role of firm size by interacting the California-headquarter indicator with proxies for firm size. As directorships at larger firms are associated with both higher compensation and higher reputational gains, we would expect larger firms to face fewer difficulties in attracting skilled female directors. Moreover, larger firms hire directors internationally, which likely gives access to a larger pool of female director candidates. In Column 1, we interact the California-headquarter dummy with the logarithm of total assets as a continuous measure of firm size, and, in Column 2, with a dummy variable that is equal to one for firms in the highest size quintile. The results in both columns suggest that firm size indeed mutes the negative quota effect, which means that in particular small firms with headquarters in California are responsible for the negative abnormal stock price reaction at California-headquartered firms observed around the adoption of the quota announcement. In particular, the results in Column 2 suggest that the negative stock return effect to California-headquartered firms is confined to firms in the smaller four size quintiles, but not to firms in the largest size quintile. Indeed, the coefficient on the interaction term is positive and slightly larger than the coefficient on the dummy variable whether the firm is incorporated in California (the combined effect of 0.19 is insignificant with a t-statistic of 0.5). Consistent with the results in Columns 1 and 2 of Table 8, Panel B of Figure 1 shows that larger firms (as proxied by index membership) 
have higher female board representation already before the quota's introduction 14

Finally, in Column 3 of Table 8 , we study the role that corporate governance plays for the abnormal stock returns following the quota law announcement. To this end, we match corporate governance data from Factset's SharkRepellent database, which enables us to construct, for each sample firm as of the quota adoption date, a corporate governance index in the spirit of Bebchuk, Cohen, and Ferrell's (2009) E-Index. Specifically, we construct a score variable to which we add one point for each of the following provisions: a poison pill, a staggered board, a supermajority vote requirement for mergers, a supermajority vote requirement to amend the charter, or a supermajority vote requirement to amend the bylaws ${ }^{15}$ The results show that the coefficient on the interaction term between the California-headquarter indicator and the (modified) E-Index is negative and significant, implying that California-headquartered firms with poor governance (i.e., more anti-takeover protection devices in place) suffer lower returns around the adoption announcement. These results suggest that firms' corporate governance structures influence firms' ability (or willingness) to attract qualified female directors.

\section{Spillover effects}

In this section, we analyze potential spillover effects of the gender quota's introduction to firms headquartered in other states than California. First, we analyze whether nonCalifornia-headquartered firms experience a negative and significant stock market reaction to the introduction of the quota as well. Second, we test for the channels through which these spillover effects materialize.

\footnotetext{
14 One concern with these results is that larger firms have higher female board representation at the onset of treatment (i.e., the announcement of the quota's introduction). However, we continue to find a statistically significant size effect once we control for female board representation.

15 We do not use ISS data, which is the basis of the E-Index, since it is not available for our sample period yet. Unfortunately, SharkRepellent does not provide information on the sixth provision of the EIndex, that is, whether the CEO's contract contains a severance agreement provision known as a "golden parachute". Hence, our modified E-Index only includes five attributes and ranges from zero to five.
} 
Results reported in Panel A of Figure 2 and Table 6 indeed show negative and significant stock market reactions to the introduction of the quota not only to Californiaheadquartered, but also to non-California-headquartered firms. In Table OA.2, we conduct our baseline event study analysis, underlying the analysis in Panel A of Table 3, for the subsamples of California-headquartered and industry- and size matched control firms separately. The results show a significantly negative stock market reaction of $-1.73 \%$ (tstatistic of -10.11) for non-California headquartered control firms over the first two trading days after the introduction of the quota in California. In summary, standard event study analysis (Table OA.2) and a calendar time portfolio analysis (Table 6) are suggestive of spillover effects of the quota law to non-California-headquartered firms and indicate that these firms, even though not directly affected by the law, still show a significantly negative market reaction to the announcement of the quota. ${ }^{16}$

There are mostly two channels through which such spillover effects are expected to operate. First, California-headquartered firms may attempt to attract female directors from the boards of non-California-headquartered companies to be able to comply with the quota. Hence, competition among firms for skilled female directors may become more intense, and some firms may even be expected to lose valuable female directors. Second, if the introduction of a mandatory gender quota in California raises concerns that other states follow by also introducing gender quotas, we would expect firms headquartered in states that are more likely to pass such laws to show more negative announcement returns to the quota. To empirically test these two channels, we retain only the matched nonCalifornia-headquartered firms in our sample and estimate regressions similar to those

\footnotetext{
${ }^{16}$ The existence of such spillover effects violates the stable unit treatment value assumption (SUTVA) underlying any difference-in-differences approach. Specifically, this assumption postulates that the outcome of some unit of observation should be unaffected by the assignment of treatment to other units. Given that the control firms also experience negative stock returns, these spillover effects most likely lead to an underestimation of the firm value effect of the quota law, that is, the return differences between Californiaheadquartered firms and the sample of control firms.
} 
reported in Tables 7 and 8. Specifically, we regress the cumulative abnormal return over the two trading days after the announcement of the quota on a firm-specific characteristic, e.g., female board representation.

To empirically test the first channel, we need a measure that quantifies the extent to which an increase in the demand for female directors at California-headquartered firms hampers the ability of non-California-headquartered firms to retain or appoint female directors. We construct two measures, which both rest on the assumption that similar firms compete for the same directors and that director supply is limited (e.g., Knyazeva, Knyazeva, and Masulis, 2013). To construct the first measure, we count, for each matched control sample firm, the total number of female directors required for all California-headquartered firms in the same two-digit SIC code industry to comply with California's female director quota (\# female directors missing). To address the problem that this measure is correlated with the number of firms in an industry, we scale it by the total number of female directors required by all firms in a two-digit SIC code industry to comply with the Californian quota, i.e., assuming that all firms - whether headquartered in California or elsewhere - have to comply to such a quota to obtain our second measure. In Column 1 of Table 9, where we use the first of the two measures, we obtain a negative coefficient that is significant at the 10\% level. In Column 2, we use the scaled variable and find the coefficient to be negative and significant at the $1 \%$ level. These results confirm that non-California-headquartered firms in industries that likely face stronger competition for female talent in the boardroom experience more negative announcement returns in response to the introduction of the quota.

Results in Tables 7 and 8 show that the market reaction to the quota's announcement was less negative for California-headquartered firms the higher the fraction of female outside directors on the board and the larger the firm. In Column 3 of Table 9, we test whether we find similar patterns in the spillover effects to non-California-headquartered firms. To 
this end, we interact a dummy variable indicating whether a firm is in the highest total assets quintile with the fraction of female directors on the board while controlling for the two stand-alone variables. The results show that a larger female board representation is associated with more negative spillover effects. However, the coefficient on the interaction term is positive, significant, and larger in magnitude than the coefficient on the female board representation variable, suggesting that the negative spillover effect is not only muted for large firms but even reversed. Hence, smaller firms not headquartered in California may be at risk of losing valuable female directors to (larger) California-headquartered firms. In Column 4 , we follow the idea that certain directors at non-California-headquartered firms may receive offers to join the boards of California-headquartered firms. As a proxy for the propensity to leave a given firm, we compute the natural logarithm of the average tenure of the female directors on the board. Naturally, this measure can only be computed for firms with at least one female director on the board, so the number of observations is reduced. Still, we find that the tenure of the female directors on the board is positively correlated with the returns of non-California-headquartered firms, consistent with the notion that firms experience a more negative stock price reaction the more likely it is to lose a female director.

In Columns 5 to 7 of Table 9, we explore the second channel: The negative spillover effect might also be driven by the propensity of a given non-California-headquartered firm to become subject to similar gender quota regulation in the future. Given the opposing views of the Democratic and Republican parties on the controversial issue of gender legislation for corporate boards, we use the local political orientation as a proxy for the propensity to become subject to a similar quota. To this end, we collect the state-level results of the 2016 Presidential Election for the Republican and Democratic Party and assign firms to states based on the location of their headquarters. In Column 5 (6), we find that firms with headquarters outside California but in states with a higher share of votes obtained 
by the Democratic (Republican) party experience more negative (positive) announcement returns around the adoption of the gender quota in California. Similarly, in Column 7, we use an indicator variable labeled Trump (d) which is equal to one if a firm is headquartered in a state where the majority of the votes were obtained by the Republican Party. Consistent with the results shown in the previous two columns, the coefficient on this variable is positive and significant.

In summary, our results show that the introduction of the gender legislation in California was associated with negative announcement returns not only at California-headquartered, but also at non-California-headquartered firms. These findings are consistent with spillover effects of the California gender quota to non-California headquartered firms. Moreover, we find evidence in support of two channels through which these spillover effects may operate: First, firms that are more likely to face difficulties in appointing or retaining female directors have more negative returns, and, second, firms that are more likely to become subject to a future gender quota law also show more negative announcement returns.

\section{The impact of the quota on board structure}

\subsection{The impact of the quota on female board representation}

Gender quotas introduced in other countries have been shown to be an effective way to

force firms to increase female board representation. In Norway, for instance, the share of female board representation has increased from around $10 \%$ in 2003 , the year the Norwegian Parliament passed the quota law, to about $40 \%$ in 2008 , the year the quota had to be fulfilled (Ahern and Dittmar, 2012). In the case of California's quota, however, it is a priori unclear whether firms will respond by restructuring their boards for at least three reasons. First, the new legislation prioritizes one gender over the other, thereby potentially conflicting with the US Constitution, the California Constitution, and Civil Rights Law. 
Second, it may violate the internal affairs doctrine, which postulates that matters involving the board of directors are subject to the laws of the state of incorporation and not where the headquarters are located (Grundfest, 2018). Not surprisingly, at least 30 business groups already indicated their willingness to challenge the law (California Chamber of Commerce, 2018). Third, while the penalty for non-compliance in Norway is a forced liquidation of the company, non-compliance with the Californian quota is penalized with a fine that seems rather small at least from the perspective of the larger firms in the sample.

Even though the adoption of the quota in California took place only recently, we conduct a preliminary analysis with the goal of testing whether California-headquartered firms respond to the quota law, that is, whether they already started to increase the share of female directors on the board relative to a sample of matched control firms headquartered outside California. Figure 3 shows the change in mean female board representation relative to the introduction of the quota on September 30,2018, in percentage points on a daily basis from August 1 to November 30 using board data from BoardEx. The solid lines show these changes for the treatment sample (in black) and the industry- and size matched control sample (in grey). Consistent with the notion that California's quota effectively and timely affects female board representation, California-headquartered firms appear to start responding to the quota by increasing female board representation relative to the sample of control firms already two weeks after the adoption of the quota law. Moreover, California-headquartered firms in need of at least two female directors to comply with the quota's requirement (black dashed line) seem to respond stronger when compared to the other firms headquartered in California and the non-California-headquartered control firms that need at least two female directors to fulfill the quota (grey dashed line).

To analyze this pattern in a regression framework, we estimate, for each firm, the fraction of female directors on the board at the end of September, October, and November 2018, which results in a firm-month panel containing up to three monthly observations per 
firm. We then regress the fraction of female directors on the board on dummy variables for the month of observation, omitting September, and interaction terms between the California headquarter dummy and the month dummy variables. To account for timeinvariant unobserved heterogeneity at the firm level, we add firm fixed effects. To account for within-correlation of different observations on one specific firms, the standard errors are clustered at the firm level. The coefficients on the month dummies indicate the percentage points by which female board representation has changed, on average, across all sample firms compared to the introduction of the quota at the end of September 2018. The coefficients on the interaction terms are the difference-in-differences estimators, that is, the average difference in the change of female board representation of Californian firms relative to the control firms in a given month. If the quota law already had a statistically significant impact on female board representation at firms headquartered in California, the difference-in-differences estimators would show a positive and significant coefficient.

The results in Column 1 of Table 10 show that female board representation at Californiaheadquartered firms indeed increased relative to the sample of non-California-headquartered control firms. Specifically, one month after the quota's introduction, the difference amounts to 0.19 percentage points but is insignificant at conventional levels. Two months after the quota's introduction, the difference increases to 0.36 percentage points, which is statistically significant at the $10 \%$ level. Next, we test whether firms under more pressure to appoint female directors respond stronger to the introduction of the quota. In Column 2 , we, therefore, retain only firms in the sample that need at least one female director to comply with the quota at announcement, and, in Column 3, we retain only firms that need at least two female directors. Consistent with our expectations, we find that the interaction terms between the California-headquarter dummy and the month dummy variables increase monotonically from Column 1 to Column 3. Specifically, California-headquartered firms that require one (two) female directors to comply with the quota on average increased 
female board representation by $0.50(0.55)$ percentage points relative to the control firms. Finally, the results in Table 10 show that both the October-end and November-end dummy variables are positive and significant, suggesting that both California headquartered and non-California-headquartered firms significantly increased female board representation in the first two months after the introduction of the quota - but at the difference-in-differences estimates show, California-headquartered firms even more than others.

In summary, these results imply that California's female board quota, although argued to be lacking teeth, is taken seriously by companies, which seem to respond by significantly increasing the share of female directors on the board already within two months after adoption of the quota.

\subsection{The impact of the quota on director skills}

In this subsection, we test whether the introduction of the quota is associated with shifts of board skills at California-headquartered firms. Such a shift would be expected if California-headquartered firms appointed male directors with a certain skill set before the introduction of the quota, and are now forced to dismiss some of these directors when recruiting female replacements from a pool of candidates with different characteristics. To test this empirically, we follow Ahern and Dittmar (2012) and compare the characteristics of newly appointed, leaving, and incumbent directors for the time period between the introduction of the quota (September 30, 2018) and the last month-end for which board data is available from BoardEx (November 30, 2018). Table 11 shows that Californiaheadquartered firms appointed 74 directors (32 or $43 \%$ females), dismissed 68 directors (5 or $7 \%$ females), and kept 7,084 directors (1,167 or 16\% females) in this time period. For each director, we compute a range of measures that proxy for her characteristics and show 
results for a selected subset.17

In the following tests, we focus on California-headquartered firms and compare the characteristics of newly appointed female directors with the characteristics of incumbent female and male directors (Panel A of Table 11) as well as appointed male and leaving female directors (Panel B of Table 11). Not surprisingly, results show that newly appointed female directors are significantly younger than incumbent female and male directors as well as leaving male directors. More telling is a comparison of newly appointed female directors and newly appointed male directors, which also indicates that newly appointed female directors are around 2.5 years younger, but the difference is not significant at conventional levels (t-statistic of -1.39). We also study more sophisticated measures of experience than director age. Results show that newly appointed female directors are significantly less likely to possess work experience at another firm in the same two-digit SIC code industry (industry experience), experience as a director of another listed firm, and experience as an outside director of another listed firm than incumbent female and male directors (Panel A). Although results for comparisons between newly appointed and leaving female directors are similar in economic terms, they lack statistical power due to the small sample sizes. We also test whether newly appointed female directors differ from the other director types in terms of their current occupation. These tests provide some evidence that newly appointed female outside directors are more likely to be employed in lower-level executive positions at other firms, for instance, as a Vice President, and are less likely to be employed as top executives at other firms, for example, as an inside director or a CEO, but differences are not statistically significant for all comparisons. Finally, we find some evidence that newly appointed female directors are less likely to qualify as independent outside director when

\footnotetext{
${ }^{17}$ For newly appointed directors, we compute time-varying measures as of the date she joins the board of a given firm. For leaving directors, we compute time-varying measures as of the date she leaves the board of a given firm. For incumbent directors, we compute time-varying measures as of the last calendar day of a given month.
} 
compared to incumbent female and male directors.

Even though these results are based on a small sample of board changes and should be considered preliminary, it is still important to emphasize that several of the characteristics underrepresented among female directors appointed to California-headquartered firms following the introduction of the quota have shown to be significantly related to firm performance. For instance, Drobetz, Oesch, Schmid, and von Meyerinck (2018) and Hoitash, Hoitash, and Faleye (2018) show that director industry experience is positively related to firm value. Fich (2005) and Fahlenbrach, Low, and Stulz (2010) find that directors simultaneously serving as CEOs in other firms are associated with higher firm values. Knyazeva, Knyazeva, and Masulis (2013) document similar findings for independent outside directors.

In summary, these preliminary results are in line with both results reported in Ahern and Dittmar (2012) for the Norwegian quota and anecdotal evidence on female director characteristics in the US. ${ }^{18}$ Moreover, these results are consistent with the notion that reductions in value at firms headquartered in California around the adoption of the quota are at least in part driven by shifts in investors' expectations regarding future board quality, likely caused by a limited supply of skilled female candidates that prevent firms from appointing directors that maximize firm value.

\section{Conclusion}

Even though the percentage of female university graduates increases each year and women successfully establish themselves in many academic profiles, such as law and medicine, women are still heavily underrepresented in corporate leadership positions. Many countries

\footnotetext{
18 Tricia Griffith, one of the few female CEOs in an S\&P500 firm, commented on potential limited supply concerns caused by California's gender quota in the Fortune magazine on October 3: "We need to look deeper in organizations [for female candidates]. If you want someone that has a CEO role to their name, you're going to be very limited. So you need to go a layer deeper, then another layer. And those women and people are hard at work in operating roles that have a lot of value." See http://fortune.com/2018/10/03/women-boards-california/.
} 
around the work recently introduced or currently discuss a board gender quota to achieve an increase in female representation on corporate boards. On September 30, 2018, California became the first US state to introduce a mandatory board gender quota applicable to all publicly-traded firms headquartered in the state. In this paper, we analyze the value consequence of this quota, potential spillover effects to firms headquartered in other states, and consequences for the director labor market.

We find that the introduction of the gender quota law is associated with significantly negative announcement returns to California-headquartered firms. This result withstands a battery of robustness tests, including the use of different event windows, alternative models to estimate the expected return, different control groups, and the use of portfolios sorts analysis to mitigate cross-sectional correlation issues resulting from the study of a single event date. Consistent with the quota imposing frictions, we find the negative announcement effect to be larger for firms requiring more female directors to comply with the quota. There is also evidence of spillover effects to non-California-headquartered firms.

We find evidence in support of two channels through which these spillover effects operate: First, we find spillover effects to be larger for firms operating in industries in which California-headquartered firms lack more female directors to comply with the quota, suggesting that non-California-headquartered firms may lose valuable female directors to California-headquartered firms. Second, we document negative spillover effects for firms headquartered in states dominated by the Democratic Party, consistent with the idea that these firms are more likely to become subject to a board gender quota as well. Finally, we show that, already as of month-end November, California-headquartered firms respond to the quota by increasing female board representation relative to a set of control firms. Newly appointed female directors differ significantly in terms of age, independence, and experience from newly appointed male directors, but also from incumbent and leaving female and male directors. 


\section{References}

Ahern, K.R., and A.K. Dittmar, 2012, The changing of the boards: The impact on firm valuation of mandated female board representation, Quarterly Journal of Economics 127, 137-197.

Amihud, Y., and S. Stoyanov, 2017, Do staggered boards harm shareholders?, Journal of Financial Economics 123, 432-439.

Bebchuk, L.A., A. Cohen, and A. Ferrell, 2009, What matters in Corporate Governance?, Review of Financial Studies 22, 783-827.

Bertrand, M., S.E. Black, S. Jensen, and A. Lleras-Muney, 2018, Breaking the glass ceiling? The effect of board quotas on female labor market outcomes in Norway, Review of Economic Studies, forthcoming.

California Chamber of Commerce, 2018, CalChamber bill positions, available at http:// ctweb.capitoltrack.com/public/search.aspx?t=bill\&s $=\mathrm{SB} 826 \&$ go $=$ Search\&session=17\&id =1dae9efb-651d-4a02-a05d-360ca7965b14.

Chaochharia, V., S. Ghosh, A. Niessen-Ruenzi, and C. Schneider, 2017, Child care provision and women's careers in firms, Working Paper, University of Mannheim.

Custódio, C., M.A. Ferreira, and P. Matos, 2013, Generalists versus specialists: Lifetime work experience and chief executive officer pay, Journal of Financial Economics 108, 471492 .

Drobetz, W., F. von Meyerinck, D. Oesch, and M. Schmid, 2018, Industry expert directors, Journal of Banking and Finance 92, 195-215.

Eckbo, B.E., Nygaard, K., and K.S. Thorburn, 2018, Board gender-balancing and firm value, Working Paper, Dartmouth College.

Engelberg, J., P. Gao, and C.A. Parsons, 2013, The price of a CEO's Rolodex, Review of Financial Studies 26, 79-114.

Fahlenbrach, R., A. Low, and R.M. Stulz, 2010, Why do firms appoint CEOs as outside directors?, Journal of Financial Economics 97, 12-32,

Ferreira, D., 2015, Board diversity: Should we trust research to inform policy?, Corporate Governance: An International Review 23, 108-111.

Fich, E.M., 2005, Are some outside directors better than others? Evidence from director appointments by fortune 1000 firms, Journal of Business 78, 1943-1972.

Graham, J.R., S. Li, and J. Qiu, 2012, Managerial attributes and executive compensation, 
Review of Financial Studies 25, 144-186.

Grundfest, J., 2018, Mandating gender diversity in the corporate boardroom: The inevitable failure of California's SB 826, Working Paper, Stanford University Law School.

Hsieh, C.-T., E. Hurst, C.I. Jones, and P. Klenow, 2017, The allocation of talent and U.S. economic growth, Working Paper, University of Chicago.

Keloharju, M., S. Knüpfer, and J. Tag, 2018, What prevents female executives from reaching the top?, Working Paper, Research Institute of Industrial Economics.

Knyazeva, A., D. Knyazeva, and R.W. Masulis, 2013, The supply of corporate directors and board independence, Review of Financial Studies 26, 1561-1605. 


\section{Figure 1: Female board representation in listed US firms}

This figure shows female board representation in all listed US firms covered by the ISS (formerly RiskMetrics) Director database from calendar years 1997 to 2017. Panel A shows female board representation for different director types expressed as a fraction of board size. Inside directors are those directors classified as executives by ISS, CEOs are inside directors with current occupation description being "CEO", and outside directors are all directors that are not inside directors. Panel B shows female board representation by index membership. Board data is measured as of a firm-year's annual meeting date. Observations are assigned to the calendar year in which an annual meeting takes place. Index membership is determined as of the annual meeting date using index constituent data provided by Compustat.

Panel A: Female board representation by director type

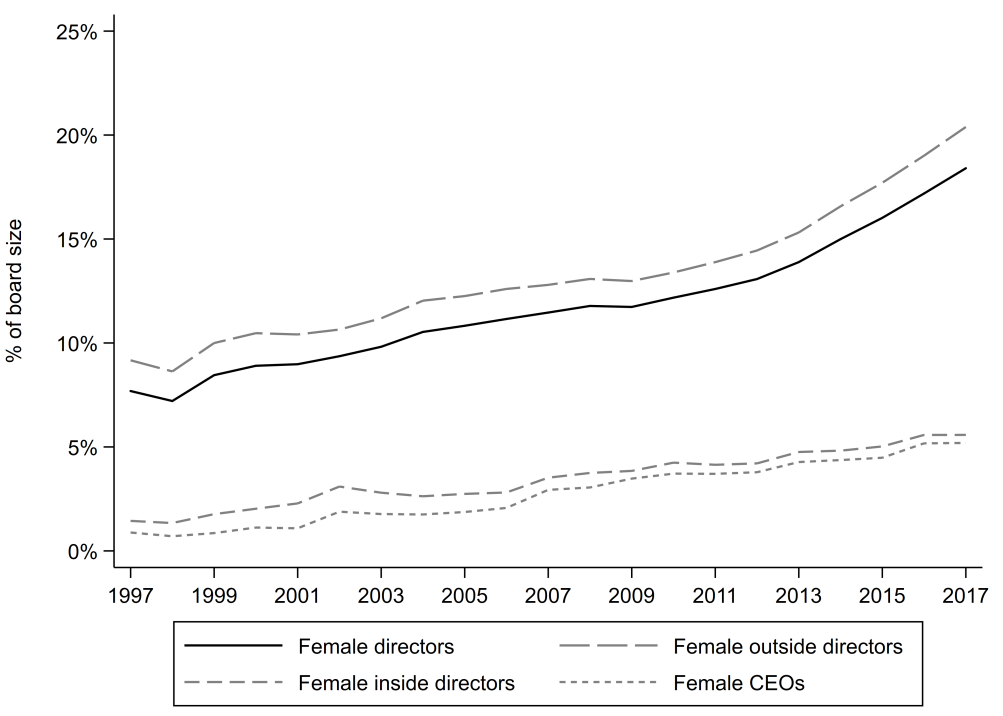

Panel B: Female board representation by index membership

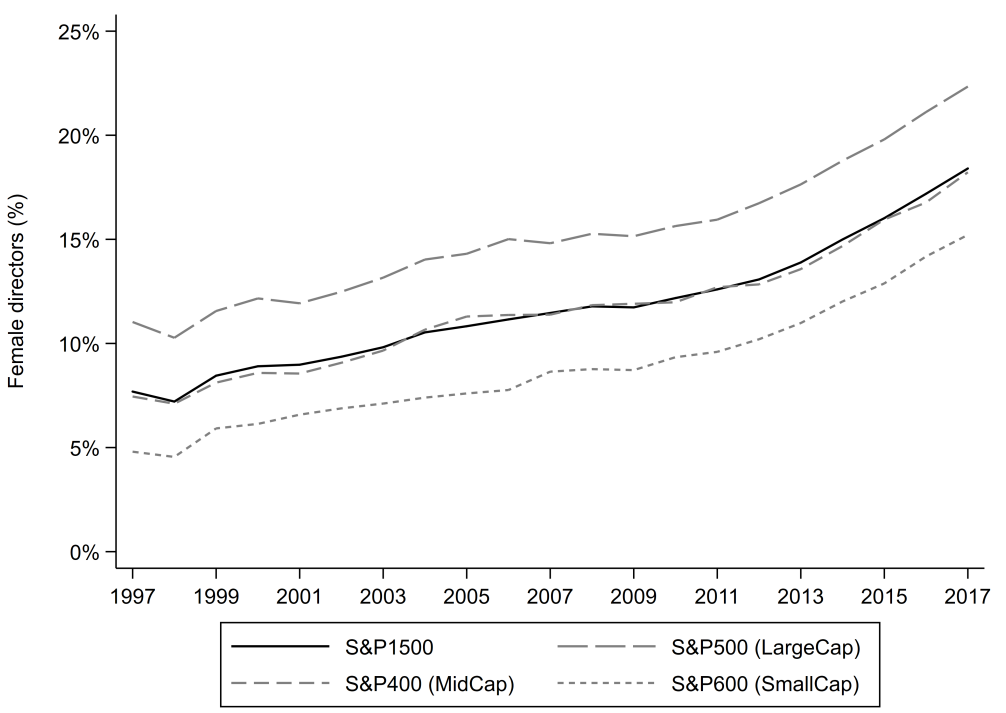


Figure 2: Abnormal returns around the event date (September 26 to October 3,2018 )

Panel A of the figure shows mean daily abnormal returns of 456 California-headquartered and 777 industryand size-matched non-California-headquartered control firms. Panel B displays differences in daily abnormal returns between the sample of California-headquartered firms and the control sample of non-Californiaheadquartered firms. Sunday, September 30, is the quota's adoption announcement date and October 1 the first trading day after the announcement, i.e., the event date. Daily abnormal returns are computed as the observed return minus the predicted return from a market model regression estimated over a 250-day estimation window that ends on Friday, September 21. As a proxy for the market return, we use the return of a self-computed, value-weighted market index consisting of all sample firms. The sample comprises all firms in Compustat with a data entry within one calendar year before September-end 2018, excluding utility and financial firms (SIC codes 4940-4949 and 6000-6999, respectively), firms with missing information on the state in which it is headquartered, firms headquartered outside the US, firms with negative book value of equity, firms with missing financial control variables, firms that only list American Depository Receipts, and firms without a listing on NYSE, AMEX, or NASDAQ. We also require at least 125 daily return observations during the 250-day estimation window and complete return data for the entire five-day event window around the event date (October 1). For each firm headquartered in California, we draw the three closest size-matched non-California-headquartered firms in the same two-digit SIC code industry as control firms. While the same firm may serve as a matched control firm to more than one Californiaheadquartered firm, every control firm is included only once in our sample. All abnormal return measures are winsorized at their 1st and 99th percentile.

Panel A: Daily abnormal returns of California- and non-California-headquartered control firms

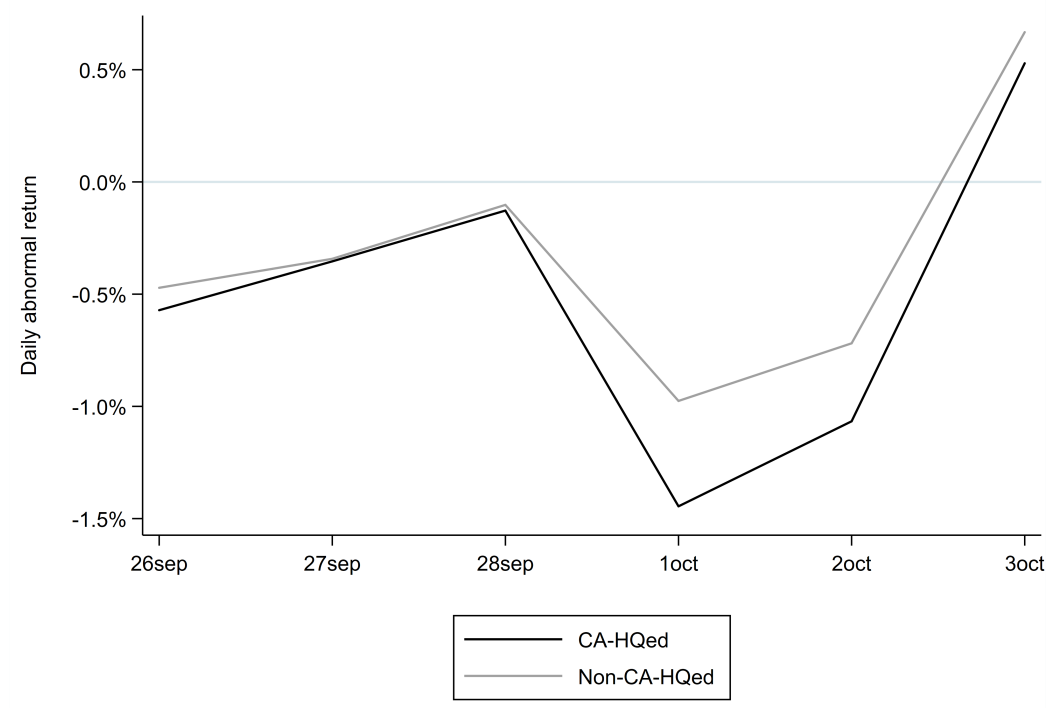


Panel B: Differences abnormal returns between California-and non-California-headquartered control firms

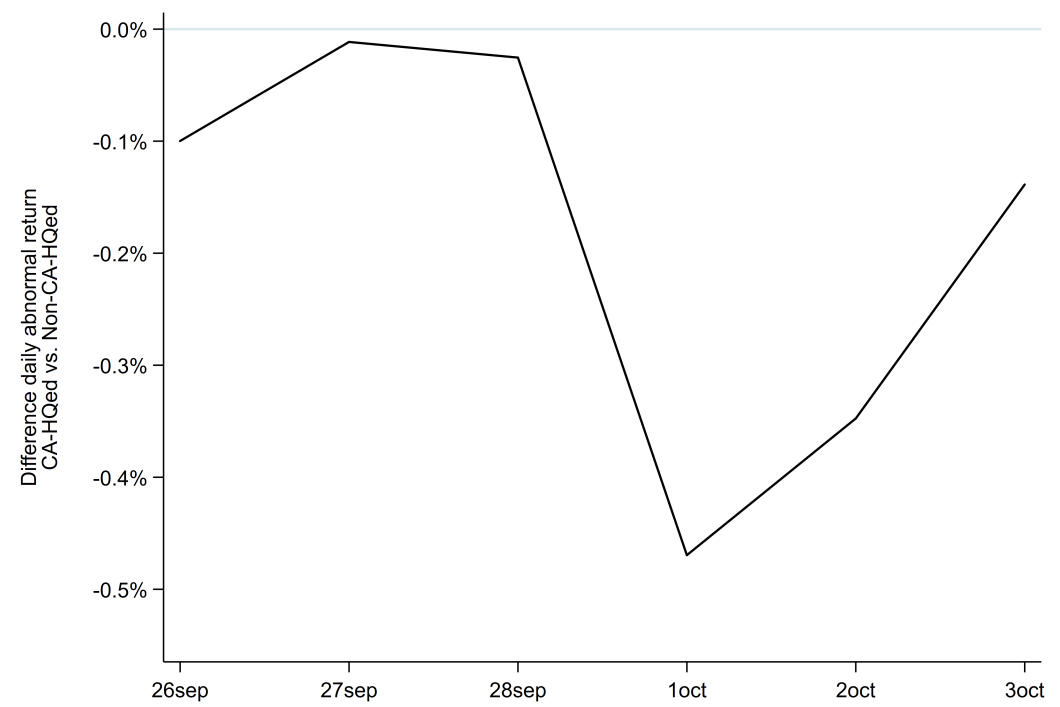


Figure 3: Changes of female board representation around quota adoption

This figure shows daily changes in female board representation for different firm samples relative to the introduction of the quota on September 30, 2018, over the time period August 1 to November 30, 2018. Solid lines show percentage point changes for a sample of California-headquartered firms (in black) and a sample of industry- and size-matched non-California-headquartered control firms (in grey). Dashed lines show changes in percentage points for subsamples of California-headquartered (in black) and nonCalifornia-headquartered firms (in grey) firms that miss more than one female director to fulfill California's board quota at the quota's introduction date. The sample comprises all firms in Compustat with a data entry within one calendar year before September-end 2018, excluding utility and financial firms (SIC codes 4940-4949 and 6000-6999, respectively), firms with missing information on the state in which it is headquartered, firms headquartered outside the US, firms with negative book value of equity, firms with missing financial control variables, firms that only list American Depository Receipts, and firms without a listing on NYSE, AMEX, or NASDAQ. We also require at least 125 daily return observations during the 250-day estimation window that ends September 21 and complete return data for the entire five-day event window around the event date (October 1). For each firm headquartered in California, we draw the three closest size-matched non-California-headquartered firms in the same two-digit SIC code industry as control firms. While the same firm may serve as a matched control firm to more than one California-headquartered firm, every control firm is included only once in our sample. Board data is obtained from BoardEx. The red vertical line indicates the date the law was signed by the Governor (September 30, 2018).

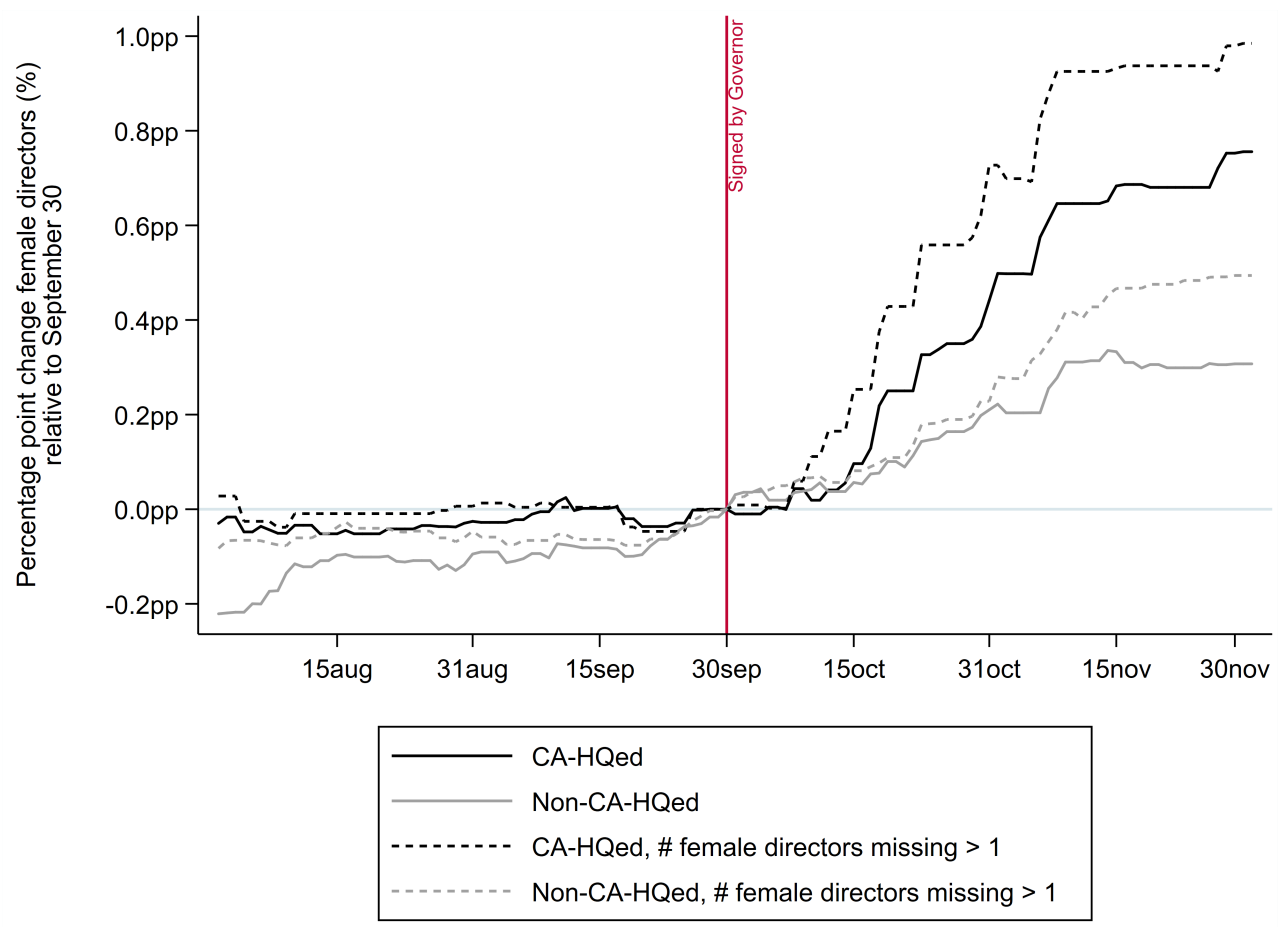




\section{Table 1: Overview of international gender legislation}

This table shows an overview of international gender legislation. We only include laws that apply to companies (not to state-owned entities), that are mandatory (not compulsory or on a comply-or-explain basis), and that carry some sort of pre-defined sanction (no potential sanctions). In the column labeled Focus, BoD indicates board of directors, SM senior management, and SB supervisory board (or "Aufsichtsrat") in Germany, which has a two-tier board system.

\begin{tabular}{|c|c|c|c|c|c|}
\hline Country & Passage date & Applicable to & Focus & Requirement & Compliance by \\
\hline Norway & $\begin{array}{l}19.12 .2003 / \\
09.12 .2005\end{array}$ & Listed firms & BoD & $\begin{array}{l}1 \text { each gender (2-3 directors), } 2(4-5) \text {, } \\
3(6-8), 4(9), 40 \%(>9)\end{array}$ & $2005 / 2008$ \\
\hline Israel & 11.03.2007 & Listed firms & $\mathrm{BoD}$ & 1 woman & 2010 \\
\hline Iceland & 04.03 .2010 & Listed and private firms & BoD & $\begin{array}{l}40 \% \text { each gender; if }<3 \text { directors, one } \\
\text { of each gender }\end{array}$ & 2013 \\
\hline France & 13.01 .2011 & $\begin{array}{l}\text { Listed firms, private firms }>500 \\
\text { employees or }>\text { EUR } 50 \mathrm{~m} \text { sales }\end{array}$ & $\mathrm{BoD}$ & $\begin{array}{l}20 \% \text { each gender } / 40 \% \text { each gender; if } \\
>8 \text { directors, difference }<2\end{array}$ & $2014 / 2017$ \\
\hline Italy & 18.06.2011 & Listed firms & BoD & $20 \%$ each gender / $33.3 \%$ each gender & $2012 / 2015$ \\
\hline Belgium & 14.09.2011 & Listed firms & BoD & $33.3 \%$ each gender & $\begin{array}{l}2017 \text { (large), } 2019 \\
\text { (small) }\end{array}$ \\
\hline India & $\begin{array}{l}30.08 .2013 / \\
28.03 .2018\end{array}$ & Listed firms & BoD & 1 woman / 1 independent woman & $\begin{array}{l}2015 \text { / } 2019 \text { (large), } \\
2020 \text { (small) }\end{array}$ \\
\hline Germany & 06.03 .2015 & $\begin{array}{l}\text { Listed firms subject to } 50 \% \\
\text { co-determination law }\end{array}$ & SB & $30 \%$ each gender & 2016 \\
\hline
\end{tabular}




\section{Table 2: Descriptive statistics}

This table reports descriptive statistics for the full sample of 2,462 firms (Panel A) and a sample comprising the 456 California-headquartered firms and 777 industry- and size-matched control firms (Panel B). The sample consists of one cross-section of Compustat firms as of the quota's adoption announcement (September 30). The sample includes all firms in Compustat with a data entry within one calendar year before September-end 2018, excluding utility and financial firms (SIC codes 4940-4949 and 6000-6999, respectively), firms with missing information on the state in which it is headquartered, firms headquartered outside the US, firms with negative book value of equity, firms with missing financial control variables, firms that only list American Depository Receipts, and firms without a listing on NYSE, AMEX, or NASDAQ. We also require at least 125 daily return observations during the 250 -day estimation window that ends September 21 and complete return data for the entire five-day event window around the event date (October 1). Panel A shows descriptive statistics for the resulting sample. Panel B shows descriptive statistics for a sample in which we draw, for each firm headquartered in California, the three closest size-matched non-California-headquartered firms in the same two-digit SIC code industry as control firms. While the same firm may serve as a matched control firm to more than one California-headquartered firm, every control firm is included only once in our sample. All financial ratios are winsorized at the 1st and 99th percentiles. Detailed variable definitions are in the Appendix.

Panel A: Full sample

\begin{tabular}{lcccccc}
\hline Firm characteristic & Mean & P25 & Median & P75 & SD & N \\
\hline CA HQ (d) & 0.185 & 0.000 & 0.000 & 0.000 & 0.389 & 2,462 \\
ROA & -0.018 & -0.020 & 0.086 & 0.138 & 0.313 & 2,462 \\
Leverage & 0.221 & 0.010 & 0.201 & 0.365 & 0.196 & 2,462 \\
Total assets (in millions) & $6,350.630$ & 135.410 & 709.912 & $2,941.623$ & $28,192.785$ & 2,462 \\
PPE / TA & 0.220 & 0.044 & 0.120 & 0.311 & 0.242 & 2,462 \\
R\&D / TA & 0.084 & 0.000 & 0.008 & 0.092 & 0.160 & 2,462 \\
Board size & 8.111 & 7.000 & 8.000 & 9.000 & 2.153 & 2,455 \\
Female directors (\%) & 0.153 & 0.000 & 0.143 & 0.222 & 0.126 & 2,455 \\
2021 requ. failed (d) & 0.840 & 1.000 & 1.000 & 1.000 & 0.367 & 2,455 \\
\# female directors missing & 1.523 & 1.000 & 2.000 & 2.000 & 1.140 & 2,455 \\
Shortfall (\%) & 0.214 & 0.100 & 0.222 & 0.333 & 0.164 & 2,455 \\
\hline Panel B: California-headquartered firms and industry- and size-matched control firms & \\
\hline Firm characteristic & Mean & P25 & Median & P75 & SD & N \\
\hline CA HQ (d) & 0.370 & 0.000 & 0.000 & 1.000 & 0.483 & 1,233 \\
ROA & -0.087 & -0.179 & 0.056 & 0.126 & 0.373 & 1,233 \\
Leverage & 0.180 & 0.000 & 0.131 & 0.314 & 0.185 & 1,233 \\
Total assets (in millions) & $4,429.506$ & 80.494 & 383.635 & $1,454.511$ & $22,233.197$ & 1,233 \\
PPE / TA & 0.140 & 0.029 & 0.080 & 0.183 & 0.171 & 1,233 \\
R\&D / TA & 0.131 & 0.000 & 0.054 & 0.171 & 0.196 & 1,233 \\
Board size & 7.754 & 6.000 & 8.000 & 9.000 & 1.977 & 1,230 \\
Female directors (\%) & 0.147 & 0.000 & 0.143 & 0.222 & 0.124 & 1,230 \\
2021 requ. failed (d) & 0.875 & 1.000 & 1.000 & 1.000 & 0.331 & 1,230 \\
\# female directors missing & 1.610 & 1.000 & 2.000 & 2.000 & 1.057 & 1,230 \\
Shortfall (\%) & 0.231 & 0.111 & 0.250 & 0.333 & 0.156 & 1,230 \\
\hline
\end{tabular}




\section{Table 3: Market reaction to the quota announcement}

This table reports differences in abnormal returns to the announcement of the gender quota in California between California-headquartered and non-California-headquartered control firms. Each column shows results from a pooled ordinary least squares regression of an abnormal return measure on a dummy variable set equal to one if a firm is headquartered in California (CA HQ (d)). Panel A reports the results from the base case model, in which we compute daily abnormal returns as the observed return minus the predicted return from a market model regression estimated over a 250-day estimation window that ends on Friday, September 21. As a proxy for the market return, we use the return of a self-computed, value-weighted market index consisting of all sample firms. For each California-headquartered sample firm, the three closest firms in terms of size that are active in the same two-digit SIC code industry are chosen as matched control firms. While the same firm may serve as a matched control firm to more than one California-headquartered firm in the treatment sample, every control firm is included only once in our sample. Across columns, we vary the length of the event window. In Panel B, we use a market-adjusted model, assuming that the beta of all stocks is equal to one. In Panels $\mathrm{C}$ and $\mathrm{D}$, we use alternative matching procedures. In Panel C, we use propensity score matching to draw up to three matched control firms per California-headquartered sample firm. In Panel D, we use all non-California-headquartered firms as control firms. Panel E includes additional robustness tests for a two-day CAR that includes the event day and the subsequent day. In Columns 1 and 2, only the single closest industry- and size-matched firm or the closest propensity score matched control firm is selected into the control sample, respectively. In Column 3 , we drop penny stocks with stock prices below USD 1. Columns 4 and 5 report results for a more or less restrictive winsorization of the dependent variable, respectively. Column 6 shows results from a median regression and no winsorizing of the dependent variable. The sample comprises all firms in Compustat with a data entry within one calendar year before September-end 2018, excluding utility and financial firms (SIC codes 4940-4949 and 6000-6999, respectively), firms with missing information on the state in which it is headquartered, firms headquartered outside the US, firms with negative book value of equity, firms with missing financial control variables, firms that only list American Depository Receipts, and firms without a listing on NYSE, AMEX, or NASDAQ. We also require at least 125 daily return observations during the 250-day estimation window and complete return data for the entire five-day event window around the event date (October 1). If not otherwise noted, abnormal return measures are winsorized at the 1st and 99th percentiles. Standard errors are clustered at the two-digit SIC code industry level. All regressions include an intercept, which is not shown for brevity. Detailed variable definitions are in the Appendix. *, ${ }^{* *}$, and ${ }^{* * *}$, indicate statistical significance at the $10 \%, 5 \%$, and $1 \%$ level, respectively.

Panel A: Baseline results

\begin{tabular}{lcccccc}
\hline Dependent variable: & $\mathrm{AR}(0)$ & $\mathrm{AR}(1)$ & $\mathrm{CAR}(0,1)$ & $\mathrm{CAR}(-1,1)$ & $\mathrm{CAR}(0,2)$ & \multicolumn{2}{c}{$\mathrm{CAR}(-2,2)$} \\
\cline { 2 - 7 } & $(1)$ & $(2)$ & $(3)$ & $(4)$ & $(5)$ & $(6)$ \\
\hline \multirow{2}{*}{ CA HQ (d) } & $-0.47^{* * *}$ & $-0.35^{* *}$ & $-0.75^{* * *}$ & $-0.84^{* *}$ & $-1.01^{* * *}$ & $\begin{array}{c}-1.19^{* * *} \\
\end{array}$ \\
& $(-4.00)$ & $(-2.18)$ & $(-3.49)$ & $(-2.32)$ & $(-5.59)$ & $(-2.98)$ \\
\hline $\mathrm{R}^{2}$ & 0.00 & 0.00 & 0.01 & 0.00 & 0.01 & 0.01 \\
$\mathrm{~N}$ & 1,233 & 1,233 & 1,233 & 1,233 & 1,233 & 1,233 \\
\hline Panel B: Market-adjusted model & & & & & \\
\hline Dependent variable: & $\mathrm{AR}(0)$ & $\mathrm{AR}(1)$ & $\mathrm{CAR}(0,1)$ & $\mathrm{CAR}(-1,1)$ & $\mathrm{CAR}(0,2)$ & $\mathrm{CAR}(-2,2)$ \\
\cline { 2 - 7 } & $(1)$ & $(2)$ & $(3)$ & $(4)$ & $(5)$ & $(6)$ \\
\hline \multirow{2}{*}{$\mathrm{CA}$ HQ (d) } & $-0.43^{* * *}$ & $-0.35^{* *}$ & $-0.74^{* * *}$ & $-0.76^{* *}$ & $-1.01^{* * *}$ & $-1.02^{* * *}$ \\
& $(-4.18)$ & $(-2.46)$ & $(-3.70)$ & $(-2.52)$ & $(-5.10)$ & $(-3.64)$ \\
\hline $\mathrm{R}^{2}$ & 0.00 & 0.00 & 0.01 & 0.00 & 0.01 & 0.01 \\
$\mathrm{~N}$ & 1,233 & 1,233 & 1,233 & 1,233 & 1,233 & 1,233 \\
\hline
\end{tabular}


Panel C: Three closest propensity score matched control firms

\begin{tabular}{|c|c|c|c|c|c|c|}
\hline \multirow[t]{2}{*}{ Dependent variable: } & $\operatorname{AR}(0)$ & $\operatorname{AR}(1)$ & $\operatorname{CAR}(0,1)$ & $\operatorname{CAR}(-1,1)$ & $\operatorname{CAR}(0,2)$ & $\mathrm{CAR}(-2,2)$ \\
\hline & $(1)$ & $(2)$ & $(3)$ & $(4)$ & $(5)$ & $(6)$ \\
\hline $\mathrm{CA} H Q(\mathrm{~d})$ & $\begin{array}{c}-0.40^{* * *} \\
(-3.81)\end{array}$ & $\begin{array}{c}-0.43^{* *} \\
(-2.12)\end{array}$ & $\begin{array}{c}-0.79^{* * *} \\
(-3.26)\end{array}$ & $\begin{array}{c}-0.85^{* *} \\
(-2.15)\end{array}$ & $\begin{array}{c}-0.98^{* * *} \\
(-3.67)\end{array}$ & $\begin{array}{l}-1.29^{* *} \\
(-2.34)\end{array}$ \\
\hline $\mathrm{R}^{2}$ & 0.00 & 0.00 & 0.01 & 0.01 & 0.01 & 0.01 \\
\hline $\mathrm{N}$ & 1,198 & 1,198 & 1,198 & 1,198 & 1,198 & 1,198 \\
\hline \multicolumn{7}{|c|}{ Panel D: All non-CA headquarted firms as control firms } \\
\hline \multirow[t]{2}{*}{ Dependent variable: } & $\operatorname{AR}(0)$ & $\operatorname{AR}(1)$ & $\operatorname{CAR}(0,1)$ & $\operatorname{CAR}(-1,1)$ & $\operatorname{CAR}(0,2)$ & $\mathrm{CAR}(-2,2)$ \\
\hline & $(1)$ & $(2)$ & $(3)$ & $(4)$ & $(5)$ & $(6)$ \\
\hline $\mathrm{CA} H Q(\mathrm{~d})$ & $\begin{array}{c}-0.58^{* * *} \\
(-3.92)\end{array}$ & $\begin{array}{c}-0.47^{* *} \\
(-2.52)\end{array}$ & $\begin{array}{c}-1.01^{* * *} \\
(-3.66)\end{array}$ & $\begin{array}{c}-1.12^{* * *} \\
(-2.92)\end{array}$ & $\begin{array}{c}-1.11^{* * *} \\
(-3.92)\end{array}$ & $\begin{array}{c}-1.26^{* * *} \\
(-3.47)\end{array}$ \\
\hline $\mathrm{R}^{2}$ & 0.01 & 0.00 & 0.01 & 0.01 & 0.01 & 0.01 \\
\hline $\mathrm{N}$ & 2,462 & 2,462 & 2,462 & 2,462 & 2,462 & 2,462 \\
\hline \multicolumn{7}{|c|}{ Panel E: Additional robustness tests } \\
\hline \multirow{2}{*}{$\begin{array}{l}\text { Dependent variable: } \\
\text { Estimator: }\end{array}$} & \multicolumn{6}{|c|}{$\operatorname{CAR}(0,1)$} \\
\hline & OLS & OLS & OLS & OLS & OLS & $\begin{array}{c}\text { Median } \\
\text { regression }\end{array}$ \\
\hline Control group: & $\begin{array}{c}\text { Closest TA } \\
\text { matches }\end{array}$ & $\begin{array}{c}\text { Closest PS } \\
\text { matches }\end{array}$ & \multicolumn{4}{|c|}{ Closest 3 TA matches } \\
\hline Excluded: & - & - & Price $<1 \$$ & - & - & - \\
\hline \multirow[t]{2}{*}{ Winsorizing: } & $1 \% \& 99 \%$ & $1 \% \& 99 \%$ & $1 \% \& 99 \%$ & $0.5 \% \& 99.5 \%$ & $5 \% \& 95 \%$ & - \\
\hline & $(1)$ & $(2)$ & $(3)$ & $(4)$ & & \\
\hline $\mathrm{CA} \mathrm{HQ}(\mathrm{d})$ & $\begin{array}{l}-0.53^{*} \\
(-1.88)\end{array}$ & $\begin{array}{c}-0.96^{* * *} \\
(-4.96)\end{array}$ & $\begin{array}{c}-0.62^{* *} \\
(-2.67)\end{array}$ & $\begin{array}{c}-0.93^{* * *} \\
(-3.91)\end{array}$ & $\begin{array}{c}-0.63^{* * *} \\
(-3.52)\end{array}$ & $\begin{array}{c}-0.64^{* * *} \\
(-2.71)\end{array}$ \\
\hline $\mathrm{R}^{2}$ & 0.00 & 0.00 & 0.00 & 0.01 & 0.01 & \\
\hline $\mathrm{N}$ & 810 & 792 & 1,186 & 1,233 & 1,233 & 1,233 \\
\hline
\end{tabular}


Table 4: Robustness tests: Control variables and alternative event dates

This table reports results from pooled ordinary least squares regressions of cumulative abnormal returns (CARs) on a dummy variable set equal to one if a firm is headquartered in California (CA HQ (d)), a set of financial control variables, and industry fixed effects. In Columns 1 to 5, CARs are estimated over two-day windows that include the event date and the first day after (i.e., October 1 and 2). In Columns 6 and 7, CARs are estimated over two-day windows that include the day of the introduction of the law (January 3 ) and the day after. In Columns 8 and 9, CARs are estimated over two-day windows that include the day of the first Assembly vote (May 31) and the day after. In Columns 10 and 11, CARs are estimate over three-day windows that include the day of the Senate vote (August 29), the day of the second Assembly vote (August 30), and the day after. Daily abnormal returns are computed as the observed return minus the predicted return from a market model regression estimated over a 250-day estimation window that ends on Friday, September 21. As a proxy for the market return, we use the return of a self-computed, value-weighted market index consisting of all sample firms. The sample comprises all firms in Compustat with a data entry within one calendar year before September-end 2018, excluding utility and financial firms (SIC codes 4940-4949 and 6000-6999, respectively), firms with missing information on the state in which it is headquartered, firms headquartered outside the US, firms with negative book value of equity, firms with missing financial control variables, firms that only list American Depository Receipts, and firms without a listing on NYSE, AMEX, or NASDAQ. We also require at least 125 daily return observations during the 250-day estimation window and complete return data for the entire five-day event window around the event date (October 1). For each California-headquartered sample firm, the three closest firms in terms of size that are active in the same two-digit SIC code industry are chosen as matched control firms. While the same firm may serve as a matched control firm to more than one California-headquartered firm, every control firm is included only once in our sample. Standard errors are clustered at the two-digit SIC code industry level in Columns 1, 2, and 6 to 9, at the 1-digit SIC code level in Column 3, at the three-digit SIC code level in Column 4, and at the Fama-French 48 industry level in Column 5. The CARs and all financial ratios are winsorized at the 1st and 99th percentiles. All regressions include an intercept, which is not shown for brevity. Detailed variable definitions are in the Appendix. $*, * *$, and ${ }^{* * *}$, indicate statistical significance at the $10 \%, 5 \%$, and $1 \%$ level, respectively. 


\begin{tabular}{|c|c|c|c|c|c|c|c|c|c|c|c|}
\hline \multirow{2}{*}{$\begin{array}{l}\text { Dependent } \\
\text { variable: }\end{array}$} & \multicolumn{5}{|c|}{$\operatorname{CAR}(0,1)$} & \multicolumn{2}{|c|}{ CAR(January 3-4) } & \multicolumn{2}{|c|}{ CAR(May 31-June 1) } & \multicolumn{2}{|c|}{ CAR(August 29-31) } \\
\hline & $(1)$ & $(2)$ & $(3)$ & $(4)$ & $(5)$ & $(6)$ & $(7)$ & $(8)$ & $(9)$ & $(10)$ & $(11)$ \\
\hline CA HQ (d) & $\begin{array}{c}-0.64^{* *} \\
(-2.64)\end{array}$ & $\begin{array}{c}-0.63^{* *} \\
(-2.70)\end{array}$ & $\begin{array}{c}-0.66^{* *} \\
(-3.09)\end{array}$ & $\begin{array}{c}-0.60^{* *} \\
(-2.22)\end{array}$ & $\begin{array}{l}-0.51^{*} \\
(-1.78)\end{array}$ & $\begin{array}{c}0.21 \\
(0.65)\end{array}$ & $\begin{array}{c}0.19 \\
(0.57)\end{array}$ & $\begin{array}{c}0.43 \\
(1.52)\end{array}$ & $\begin{array}{c}0.37 \\
(1.29)\end{array}$ & $\begin{array}{c}0.38 \\
(1.20)\end{array}$ & $\begin{array}{c}0.40 \\
(1.25)\end{array}$ \\
\hline $\mathrm{ROA}$ & $\begin{array}{c}0.29 \\
(0.30)\end{array}$ & $\begin{array}{c}0.38 \\
(0.35)\end{array}$ & $\begin{array}{c}0.28 \\
(0.26)\end{array}$ & $\begin{array}{c}0.39 \\
(0.41)\end{array}$ & $\begin{array}{c}0.34 \\
(0.41)\end{array}$ & $\begin{array}{c}1.67 * * * \\
(3.64)\end{array}$ & $\begin{array}{c}1.64^{* * *} \\
(2.89)\end{array}$ & $\begin{array}{l}1.48^{*} \\
(1.79)\end{array}$ & $\begin{array}{c}1.30 \\
(1.42)\end{array}$ & $\begin{array}{c}0.31 \\
(0.39)\end{array}$ & $\begin{array}{c}0.55 \\
(0.68)\end{array}$ \\
\hline Leverage & $\begin{array}{l}1.70^{* *} \\
(2.30)\end{array}$ & $\begin{array}{l}1.35^{*} \\
(1.89)\end{array}$ & $\begin{array}{l}1.58^{*} \\
(2.07)\end{array}$ & $\begin{array}{c}1.03 \\
(1.20)\end{array}$ & $\begin{array}{l}1.26^{*} \\
(1.84)\end{array}$ & $\begin{array}{c}0.95 \\
(1.59)\end{array}$ & $\begin{array}{c}0.81 \\
(1.45)\end{array}$ & $\begin{array}{c}0.36 \\
(0.28)\end{array}$ & $\begin{array}{c}0.78 \\
(0.58)\end{array}$ & $\begin{array}{c}-0.85 \\
(-1.24)\end{array}$ & $\begin{array}{c}-0.83 \\
(-1.18)\end{array}$ \\
\hline $\ln$ (Total assets) & $\begin{array}{c}0.05 \\
(0.62)\end{array}$ & $\begin{array}{c}0.04 \\
(0.49)\end{array}$ & $\begin{array}{c}0.08 \\
(1.19)\end{array}$ & $\begin{array}{c}0.04 \\
(0.60)\end{array}$ & $\begin{array}{c}0.02 \\
(0.25)\end{array}$ & $\begin{array}{c}-0.02 \\
(-0.29)\end{array}$ & $\begin{array}{c}0.00 \\
(0.01)\end{array}$ & $\begin{array}{c}-0.14 \\
(-1.65)\end{array}$ & $\begin{array}{l}-0.15^{*} \\
(-1.78)\end{array}$ & $\begin{array}{c}-0.17^{* *} \\
(-2.05)\end{array}$ & $\begin{array}{c}-0.12 \\
(-1.20)\end{array}$ \\
\hline $\mathrm{PPE} / \mathrm{TA}$ & $\begin{array}{c}1.65 \\
(1.45)\end{array}$ & $\begin{array}{c}1.40 \\
(1.05)\end{array}$ & $\begin{array}{c}1.82 \\
(1.33)\end{array}$ & $\begin{array}{c}0.85 \\
(0.51)\end{array}$ & $\begin{array}{c}0.82 \\
(0.64)\end{array}$ & $\begin{array}{c}-0.41 \\
(-0.56)\end{array}$ & $\begin{array}{c}-0.69 \\
(-0.91)\end{array}$ & $\begin{array}{c}-0.32 \\
(-0.52)\end{array}$ & $\begin{array}{c}-0.15 \\
(-0.18)\end{array}$ & $\begin{array}{c}-0.28 \\
(-0.18)\end{array}$ & $\begin{array}{c}-0.67 \\
(-0.40)\end{array}$ \\
\hline $\mathrm{R} \& \mathrm{D} / \mathrm{TA}$ & $\begin{array}{l}-0.15 \\
(-0.15)\end{array}$ & $\begin{array}{c}0.41 \\
(0.56)\end{array}$ & $\begin{array}{c}0.25 \\
(0.59)\end{array}$ & $\begin{array}{c}0.76 \\
(0.71)\end{array}$ & $\begin{array}{c}0.58 \\
(0.52)\end{array}$ & $\begin{array}{c}4.61^{* * *} \\
(5.76)\end{array}$ & $\begin{array}{c}5.22^{* * *} \\
(4.88)\end{array}$ & $\begin{array}{c}2.51^{* *} \\
(2.59)\end{array}$ & $\begin{array}{c}2.31^{* *} \\
(2.09)\end{array}$ & $\begin{array}{l}1.71^{* *} \\
(2.23)\end{array}$ & $\begin{array}{c}1.30 \\
(1.61)\end{array}$ \\
\hline Industry FEs & - & $2-\mathrm{SIC}$ & 1-SIC & $3-\mathrm{SIC}$ & FF48 & - & $2-\mathrm{SIC}$ & - & 2-SIC & - & $2-\mathrm{SIC}$ \\
\hline $\begin{array}{l}\mathrm{R}^{2} \\
\mathrm{~N}\end{array}$ & $\begin{array}{c}0.02 \\
1,233\end{array}$ & $\begin{array}{c}0.09 \\
1,233\end{array}$ & $\begin{array}{c}0.04 \\
1,233\end{array}$ & $\begin{array}{c}0.14 \\
1,233\end{array}$ & $\begin{array}{c}0.08 \\
1,233\end{array}$ & $\begin{array}{c}0.02 \\
1,185\end{array}$ & $\begin{array}{c}0.05 \\
1,185\end{array}$ & $\begin{array}{c}0.01 \\
1,221\end{array}$ & $\begin{array}{c}0.04 \\
1,221\end{array}$ & $\begin{array}{c}0.01 \\
1,230\end{array}$ & $\begin{array}{c}0.03 \\
1,230\end{array}$ \\
\hline
\end{tabular}




\section{Table 5: Difference-in-differences estimates using daily abnormal returns}

This table reports results from pooled ordinary least squares regressions of daily abnormal returns (ARs) on a dummy variable set equal to one if a firm is headquartered in California (CA HQ (d)), a dummy set equal to one for observations measured after the implementation of the quota (Post (d)), and an interaction term between these two variables. The regression shown in Column 2 additionally includes industry fixed effects based on two-digit SIC codes, Column 3 additionally includes financial controls, and Column 4 includes firm fixed effects. The sample comprises four daily abnornmal stock return observations per firm, two before and two after the introduction of the quota. Daily abnormal returns are computed as the observed return minus the predicted return from a market model regression estimated over a 250-day estimation window that ends on Friday, September 21. As a proxy for the market return, we use the return of a self-computed, value-weighted market index consisting of all sample firms. The sample comprises all firms in Compustat with a data entry within one calendar year before September-end 2018, excluding utility and financial firms (SIC codes 4940-4949 and 6000-6999, respectively), firms with missing information on the state in which it is headquartered, firms headquartered outside the US, firms with negative book value of equity, firms with missing financial control variables, firms that only list American Depository Receipts, and firms without a listing on NYSE, AMEX, or NASDAQ. We also require at least 125 daily return observations during the 250-day estimation window and complete return data for the entire five-day event window around the event date (October 1). For each firm headquartered in California, we choose the three closest firms in terms of size that are active in the same two-digit SIC code industry. While the same firm may serve as a matched control firm to more than one California-headquartered firm, every control firm is included only once in our sample. Standard errors are clustered at the firm level. Daily abnormal returns and all financial ratios are winsorized at the 1st and 99th percentiles. All regressions include an intercept, which is not shown for brevity. Detailed variable definitions are in the Appendix. ${ }^{*},{ }^{* *}$, and ${ }^{* * *}$, indicate statistical significance at the $10 \%, 5 \%$, and $1 \%$ level, respectively.

\begin{tabular}{|c|c|c|c|c|}
\hline \multirow[t]{2}{*}{ Dependent variable: } & \multicolumn{4}{|c|}{ Daily ARs } \\
\hline & $(1)$ & $(2)$ & $(3)$ & $(4)$ \\
\hline CA HQ (d) × Post $(d)$ & $\begin{array}{c}-0.39^{* *} \\
(-2.19)\end{array}$ & $\begin{array}{c}-0.39^{* *} \\
(-2.18)\end{array}$ & $\begin{array}{c}-0.39^{* *} \\
(-2.18)\end{array}$ & $\begin{array}{l}-0.39^{*} \\
(-1.90)\end{array}$ \\
\hline Post (d) & $\begin{array}{c}-0.62 * * * \\
(-5.64)\end{array}$ & $\begin{array}{c}-0.62^{* * *} \\
(-5.63)\end{array}$ & $\begin{array}{c}-0.62^{* * *} \\
(-5.62)\end{array}$ & $\begin{array}{c}-0.62^{* * *} \\
(-4.89)\end{array}$ \\
\hline CA HQ (d) & $\begin{array}{l}-0.02 \\
(-0.15)\end{array}$ & $\begin{array}{c}0.01 \\
(0.09)\end{array}$ & $\begin{array}{c}0.04 \\
(0.27)\end{array}$ & \\
\hline $\mathrm{ROA}$ & & & $\begin{array}{l}0.61^{* *} \\
(1.97)\end{array}$ & \\
\hline Leverage & & & $\begin{array}{c}0.06 \\
(0.25)\end{array}$ & \\
\hline $\ln$ (Total assets) & & & $\begin{array}{l}0.05^{*} \\
(1.70)\end{array}$ & \\
\hline PPE / TA & & & $\begin{array}{c}0.42 \\
(0.91)\end{array}$ & \\
\hline R\&D / TA & & & $\begin{array}{c}0.27 \\
(0.48)\end{array}$ & \\
\hline Industry FEs & - & 2-SIC & 2-SIC & - \\
\hline Firm FEs & No & No & No & Yes \\
\hline $\mathrm{R}^{2}$ & 0.02 & 0.03 & 0.04 & 0.30 \\
\hline $\mathrm{N}$ & 4,932 & 4,932 & 4,932 & 4,932 \\
\hline Firms & 1,233 & 1,233 & 1,233 & 1,233 \\
\hline
\end{tabular}




\section{Table 6: Robustness test: Accounting for the cross-sectional dependence of returns}

This table reports cumulative abnormal stock returns for two portfolios, one comprising California-headquartered firms (CA HQ (d) = 1) and the other comprising a sample of industry- and size-matched non-Californiaheadquartered firms $(\mathrm{CA} \mathrm{HQ}(\mathrm{d})=0)$. The estimate for the daily abnormal return $A R$ is obtained from estimating the following regression:

$$
r_{t}=\alpha+A R d_{t}+\beta r_{w t}+\epsilon_{t}
$$

where $r_{t}$ is the daily equally-weighted portfolio return of all portfolio firms in excess of the 1-month US treasury bill rate, $d_{t}$ is a dummy variable set equal to one for observations in the event window and zero for observations in the estimation window, and $r_{w t}$ is the daily value-weighted market index return in excess of the 1-month US treasury bill rate. As a proxy for the market return, we use the return of a self-computed, value-weighted market index consisting of all sample firms. The regression is estimated over a sample that includes all observations from the 250-day estimation window that ends on September 21 and the event window. Estimates for the cumulative abnormal returns are obtained by multiplying the obtained coefficient for $A R$ by the number of days in the event window. Differences in abnormal returns between California-headquartered and non-California-headquartered firms are obtained from estimating the regression above but with the dependent variable being the daily difference in portfolio returns of California-headquartered and non-California-headquartered firms. The sample comprises all firms in Compustat with a data entry within one calendar year before September-end 2018, excluding utility and financial firms (SIC codes 4940-4949 and 6000-6999, respectively), firms with missing information on the state in which it is headquartered, firms headquartered outside the US, firms with negative book value of equity, firms with missing financial control variables, firms that only list American Depository Receipts, and firms without a listing on NYSE, AMEX, or NASDAQ. We also require at least 125 daily return observations during the 250-day estimation window and complete return data for the entire five-day event window around the event date (October 1). For each firm headquartered in California, we choose the three closest firms in terms of size that are active in the same two-digit SIC code industry. While the same firm may serve as a matched control firm to more than one California-headquartered firm, every control firm is included only once in our sample. Detailed variable definitions are in the Appendix. *, **, and ***, indicate statistical significance at the $10 \%, 5 \%$, and $1 \%$ level, respectively.

\begin{tabular}{|c|c|c|c|c|c|c|c|c|}
\hline & \multicolumn{3}{|c|}{$\mathrm{CA} \mathrm{HQ}(\mathrm{d})=1$} & \multicolumn{3}{|c|}{$\mathrm{CA} \mathrm{HQ}(\mathrm{d})=0$} & \multicolumn{2}{|c|}{ Differences } \\
\hline & Mean & t-value & Firms & Mean & $\mathrm{t}$-value & Firms & Mean & t-value \\
\hline $\mathrm{AR}(0)$ & $-1.26 \% * *$ & -2.56 & 456 & $-0.82 \% * *$ & -2.05 & 777 & $-0.44 \% *$ & -1.80 \\
\hline $\mathrm{AR}(1)$ & $-0.94 \% *$ & -1.90 & 456 & $-0.63 \%$ & -1.57 & 777 & $-0.31 \%$ & -1.26 \\
\hline $\operatorname{CAR}(0,1)$ & $-2.20 \% * * *$ & -3.15 & 456 & $-1.44 \% * *$ & -2.56 & 777 & $-0.76 \% * *$ & -2.16 \\
\hline $\operatorname{CAR}(-1,1)$ & $-2.16 \% * *$ & -2.50 & 456 & $-1.39 \% * *$ & -1.99 & 777 & $-0.77 \% *$ & -1.80 \\
\hline CAR $(0,2)$ & $-1.53 \% *$ & -1.75 & 456 & $-0.62 \%$ & -0.87 & 777 & $-0.91 \% * *$ & -2.12 \\
\hline $\operatorname{CAR}(-2,2)$ & $-1.67 \%$ & -1.48 & 456 & $-0.71 \%$ & -0.77 & 777 & $-0.97 \% *$ & -1.74 \\
\hline
\end{tabular}




\section{Table 7: Cross-sectional tests: Quota compliance and female board represen-}

tation

This table reports results from pooled ordinary least squares regressions of two-day cumulative abnormal returns (CARs) on a dummy variable set equal to one if a firm is headquartered in California (CA HQ (d)), a variable related to quota compliance or female board representation, and an interaction term between these two. Daily abnormal returns are computed as the observed return minus the predicted return from a market model regression estimated over a 250-day estimation window that ends on Friday, September 21. As a proxy for the market return, we use the return of a self-computed, value-weighted market index consisting of all sample firms. The sample comprises all firms in Compustat with a data entry within one calendar year before September-end 2018, excluding utility and financial firms (SIC codes 4940-4949 and 6000-6999, respectively), firms with missing information on the state in which it is headquartered, firms headquartered outside the US, firms with negative book value of equity, firms with missing financial control variables, firms that only list American Depository Receipts, and firms without a listing on NYSE, AMEX, or NASDAQ. We also require at least 125 daily return observations during the 250-day estimation window and complete return data for the entire five-day event window around the event date (October 1). For each firm headquartered in California, we choose the three closest firms in terms of size that are active in the same two-digit SIC code industry. While the same firm may serve as a matched control firm to more than one California-headquartered firm, every control firm is included only once in our sample. Standard errors are clustered at the two-digit SIC code level. Cumulative abnormal returns are winsorized at the 1st and 99th percentiles. All regressions include an intercept, which is not shown for brevity. Detailed variable definitions are in the Appendix. ${ }^{*}, * *$, and ${ }^{* * *}$, indicate statistical significance at the $10 \%, 5 \%$, and $1 \%$ level, respectively.

\begin{tabular}{|c|c|c|c|c|}
\hline \multirow[t]{2}{*}{ Dependent variable: } & \multicolumn{4}{|c|}{$\operatorname{CAR}(0,1)$} \\
\hline & $(1)$ & $(2)$ & $(3)$ & $(4)$ \\
\hline CA HQ (d) & $\begin{array}{l}1.56^{* *} \\
(2.07)\end{array}$ & $\begin{array}{c}0.13 \\
(0.26)\end{array}$ & $\begin{array}{c}0.24 \\
(0.52)\end{array}$ & $\begin{array}{c}-1.33^{* * *} \\
(-3.30)\end{array}$ \\
\hline CA HQ $($ d $) \times 2021$ requ. failed $(d)$ & $\begin{array}{c}-2.58^{* * *} \\
(-3.89)\end{array}$ & & & \\
\hline 2021 requ. failed $(\mathrm{d})$ & $\begin{array}{c}0.51 \\
(1.30)\end{array}$ & & & \\
\hline CA HQ $(d) \times \#$ female directors missing & & $\begin{array}{l}-0.52^{*} \\
(-1.83)\end{array}$ & & \\
\hline \# female directors missing & & $\begin{array}{c}0.04 \\
(0.22)\end{array}$ & & \\
\hline CA HQ (d) × Shortfall $(\%)$ & & & $\begin{array}{l}-4.12^{* *} \\
(-2.28)\end{array}$ & \\
\hline Shortfall (\%) & & & $\begin{array}{c}0.78 \\
(0.75)\end{array}$ & \\
\hline CA HQ $(\mathrm{d}) \times$ Female directors $(\%)$ & & & & $\begin{array}{l}4.13^{*} \\
(1.93)\end{array}$ \\
\hline Female directors $(\%)$ & & & & $\begin{array}{l}-1.63 \\
(-1.49)\end{array}$ \\
\hline $\mathrm{R}^{2}$ & 0.01 & 0.01 & 0.01 & 0.01 \\
\hline $\mathrm{N}$ & 1,230 & 1,230 & 1,230 & 1,230 \\
\hline
\end{tabular}




\section{Table 8: Cross-sectional tests: Firm size and corporate governance}

This table reports results from pooled ordinary least squares regressions of two-day cumulative abnormal returns (CARs) on a dummy variable set equal to one if a firm is headquartered in California (CA HQ (d)), a variable related to firm size or corporate governance, and an interaction term between these two. Daily abnormal returns are computed as the observed return minus the predicted return from a market model regression estimated over a 250-day estimation window that ends on Friday, September 21. As a proxy for the market return, we use the return of a self-computed, value-weighted market index consisting of all sample firms. The sample comprises all firms in Compustat with a data entry within one calendar year before September-end 2018, excluding utility and financial firms (SIC codes 4940-4949 and 6000-6999, respectively), firms with missing information on the state in which it is headquartered, firms headquartered outside the US, firms with negative book value of equity, firms with missing financial control variables, firms that only list American Depository Receipts, and firms without a listing on NYSE, AMEX, or NASDAQ. We also require at least 125 daily return observations during the 250-day estimation window and complete return data for the entire five-day event window around the event date (October 1). For each firm headquartered in California, we choose the three closest firms in terms of size that are active in the same two-digit SIC code industry. While the same firm may serve as a matched control firm to more than one California-headquartered firm, every control firm is included only once in our sample. Standard errors are clustered at the two-digit SIC code level. Cumulative abnormal returns are winsorized at the 1st and 99th percentiles. All regressions include an intercept, which is not shown for brevity. Detailed variable definitions are in the Appendix. ${ }^{*},{ }^{* *}$, and ${ }^{* * *}$, indicate statistical significance at the $10 \%, 5 \%$, and $1 \%$ level, respectively.

\begin{tabular}{|c|c|c|c|}
\hline \multirow[t]{2}{*}{ Dependent variable: } & \multicolumn{3}{|c|}{$\operatorname{CAR}(0,1)$} \\
\hline & $(1)$ & $(2)$ & $(3)$ \\
\hline CA HQ (d) & $\begin{array}{c}-2.21^{* * *} \\
(-3.95)\end{array}$ & $\begin{array}{c}-0.90^{* * * *} \\
(-3.80)\end{array}$ & $\begin{array}{c}0.03 \\
(0.06)\end{array}$ \\
\hline CA HQ (d) × ln(Total assets) & $\begin{array}{c}0.24^{* * *} \\
(3.16)\end{array}$ & & \\
\hline $\ln$ (Total assets) & $\begin{array}{c}0.08 \\
(0.99)\end{array}$ & & \\
\hline CA HQ (d) × Largest size quintile (d) & & $\begin{array}{l}1.09^{* *} \\
(2.41)\end{array}$ & \\
\hline Largest size quintile (d) & & $\begin{array}{c}1.68^{* * *} \\
(4.63)\end{array}$ & \\
\hline CA HQ $(\mathrm{d}) \times$ Modified E-Index & & & $\begin{array}{l}-0.35^{* *} \\
(-2.21)\end{array}$ \\
\hline Modified E-Index & & & $\begin{array}{l}-0.09 \\
(-0.89)\end{array}$ \\
\hline $\mathrm{R}^{2}$ & 0.01 & 0.03 & 0.01 \\
\hline $\mathrm{N}$ & 1,233 & 1,233 & 1,092 \\
\hline
\end{tabular}




\section{Table 9: Spillover effects to non-California-headquartered firms}

This table reports results from pooled ordinary least squares regressions of two-day cumulative abnormal returns (CARs) on firm-specific variables for a sample of non-California-headquartered firms. Firms in this sample are selected by choosing the three closest firms in terms of size that are active in the same two-digit SIC code industry as the California-headquartered firms in our main sample. While the same firm may serve as a matched control firm to more than one California-headquartered firm, every control firm is included only once in the sample. Daily abnormal returns are computed as the observed return minus the predicted return from a market model regression estimated over a 250-day estimation window that ends on Friday, September 21. As a proxy for the market return, we use the return of a self-computed, value-weighted market index consisting of all sample firms. The sample comprises all firms in Compustat with a data entry within one calendar year before September-end 2018, excluding utility and financial firms (SIC codes 4940-4949 and 6000-6999, respectively), firms with missing information on the state in which it is headquartered, firms headquartered outside the US, firms with negative book value of equity, firms with missing financial control variables, firms that only list American Depository Receipts, and firms without a listing on NYSE, AMEX, or NASDAQ. We also require at least 125 daily return observations during the 250-day estimation window and complete return data for the entire five-day event window around the event date (October 1). Standard errors are clustered at the two-digit SIC code level. Cumulative abnormal returns are winsorized at the 1st and 99th percentiles. All regressions include an intercept, which is not shown for brevity. Detailed variable definitions are in the Appendix. * ${ }^{* *}$, and ${ }^{* * *}$, indicate statistical significance at the $10 \%, 5 \%$, and $1 \%$ level, respectively. 


\begin{tabular}{|c|c|c|c|c|c|c|c|}
\hline \multirow[t]{2}{*}{ Dependent variable: } & \multicolumn{7}{|c|}{$\operatorname{CAR}(0,1)$} \\
\hline & $(1)$ & $(2)$ & $(3)$ & $(4)$ & $(5)$ & $(6)$ & $(7)$ \\
\hline $\ln$ (Missing female directors in industry in $\mathrm{CA}$ ) & $\begin{array}{l}-0.24^{*} \\
(-1.76)\end{array}$ & & & & & & \\
\hline$\%$ missing female directors in industry in CA & & $\begin{array}{c}-5.18^{* * *} \\
(-2.98)\end{array}$ & & & & & \\
\hline Largest size quintile $(\mathrm{d}) \times$ Female directors $(\%)$ & & & $\begin{array}{l}6.37^{* *} \\
(2.49)\end{array}$ & & & & \\
\hline Female directors (\%) & & & $\begin{array}{l}-3.42^{* *} \\
(-2.60)\end{array}$ & & & & \\
\hline Largest size quintile (d) & & & $\begin{array}{c}0.55 \\
(0.68)\end{array}$ & & & & \\
\hline $\ln$ (Tenure female directors) & & & & $\begin{array}{l}0.40^{* *} \\
(2.56)\end{array}$ & & & \\
\hline$\%$ votes Democrats & & & & & $\begin{array}{l}-4.05^{*} \\
(-1.77)\end{array}$ & & \\
\hline$\%$ votes Republican & & & & & & $\begin{array}{l}5.08^{* *} \\
(2.04)\end{array}$ & \\
\hline Trump (d) & & & & & & & $\begin{array}{l}0.62^{*} \\
(1.87)\end{array}$ \\
\hline $\mathrm{R}^{2}$ & 0.01 & 0.02 & 0.02 & 0.00 & 0.01 & 0.01 & 0.00 \\
\hline $\mathrm{N}$ & 777 & 774 & 775 & 548 & 777 & 777 & 777 \\
\hline
\end{tabular}


Table 10: Changes in female board representation around quota adoption

This table reports results from pooled ordinary least squares regressions of the fraction of female directors on the board (Female directors (\%)) on a dummy variable set equal to one if a firm is headquartered in California (CA HQ (d)), month dummy variables, and interaction terms between the California-headquarter dummy and the month dummy variables. For each sample firm, we compute the fraction of female directors on the board for the end of September (the base month) as well as for the end of October and November, respectively. The sample comprises all firms in Compustat with a data entry within one calendar year before September-end 2018, excluding utility and financial firms (SIC codes 4940-4949 and 6000-6999, respectively), firms with missing information on the state in which it is headquartered, firms headquartered outside the US, firms with negative book value of equity, firms with missing financial control variables, firms that only list American Depository Receipts, and firms without a listing on NYSE, AMEX, or NASDAQ. We also require at least 125 daily return observations during the 250-day estimation window that ends September 21 and complete return data for the entire five-day event window around the event date (October 1). For each firm headquartered in California, we choose the three closest firms in terms of size that are active in the same two-digit SIC code industry. While the same firm may serve as a matched control firm to more than one California-headquartered firm, every control firm is included only once in our sample. In Column 2, we restrict the sample to firms that require at least one additional female director to fulfill the quota, and in Column 3, we restrict the sample to firms that require at least two additional female directors to fulfill the quota. All regressions include firm fixed effects. Standard errors are clustered at the firm level. Detailed variable definitions are in the Appendix. *, **, and ***, indicate statistical significance at the $10 \%, 5 \%$, and $1 \%$ level, respectively.

\begin{tabular}{lccc}
\hline Dependent variable: & \multicolumn{3}{c}{ Female directors $(\%)$} \\
\cline { 2 - 4 } Sample: & Full & $\begin{array}{c}\text { \# female directors } \\
\text { missing }>0\end{array}$ & $\begin{array}{c}\text { \# female directors } \\
\text { missing }>1\end{array}$ \\
\cline { 2 - 4 } & $(1)$ & $(2)$ & $(3)$ \\
\hline CA HQ (d) $\times$ October-end (d) & 0.19 & $0.34^{*}$ & $0.49^{* *}$ \\
CA HQ (d) $\times$ November-end (d) & $(1.16)$ & $(1.96)$ & $(2.13)$ \\
& $0.36^{*}$ & $0.50^{* *}$ & $0.55^{* *}$ \\
October-end (d) & $(1.82)$ & $(2.40)$ & $(2.03)$ \\
November-end (d) & $0.22^{* * *}$ & $0.21^{* *}$ & $0.24^{* *}$ \\
& $(2.65)$ & $(2.34)$ & $(2.09)$ \\
Firm FEs & $0.32^{* * *}$ & $0.35^{* * *}$ & $0.48^{* * *}$ \\
\hline $\mathrm{R}^{2}$ & $(3.04)$ & $(3.26)$ & $(3.38)$ \\
$\mathrm{N}$ & Yes & Yes & Yes \\
Firms & 0.02 & 0.03 & 0.04 \\
\hline
\end{tabular}




\section{Table 11: Director skills and experiences}

This table reports results of tests for differences in means between the characteristics of different director subsets. Panel A reports descriptive statistics and results of comparison tests of newly appointed and incumbent directors at California-headquartered firms in the time period September 30 to November 30, 2018, for subsets of directors based on director gender. Panel B reports descriptive statistics and results of comparison tests of newly appointed and leaving directors at California-headquartered firms in the time period September 30 to November 30, 2018, for subsets of directors based on director gender. The bottom rows display sample sizes. Characteristics of incoming directors are determined as of the first day they are on the company's board, for leaving directors as of the last day of their board membership, and as of the last day of each sample month incumbent directors serve on a board. The sample comprises all firms headquartered in California in Compustat with a data entry within one calendar year before September-end 2018, excluding utility and financial firms (SIC codes 4940-4949 and 6000-6999, respectively), firms with negative book value of equity, firms with missing financial control variables, firms that only list American Depository Receipts, and firms without a listing on NYSE, AMEX, or NASDAQ. We also require at least 125 daily return observations during the 250-day estimation window that ends September 21 and complete return data for the entire five-day event window around the event date (October 1). Detailed variable definitions are in the Appendix. *,**, and ***, indicate statistical significance at the $10 \%, 5 \%$, and $1 \%$ level, respectively. 
Panel A: Newly appointed female directors vs. incumbent female and male directors

\begin{tabular}{|c|c|c|c|c|c|c|c|c|}
\hline \multirow[b]{4}{*}{ Age (yrs) } & \multicolumn{2}{|c|}{ Newly appointed directors } & \multicolumn{2}{|c|}{ Incumbent directors } & \multicolumn{4}{|c|}{ Differences } \\
\hline & \multirow{2}{*}{$\begin{array}{c}\text { Female } \\
(1)\end{array}$} & \multirow{2}{*}{$\begin{array}{c}\text { Male } \\
(2) \\
\end{array}$} & \multirow{2}{*}{$\begin{array}{c}\text { Female } \\
(3)\end{array}$} & \multirow{2}{*}{$\begin{array}{c}\text { Male } \\
(4) \\
\end{array}$} & \multicolumn{2}{|c|}{$(1)-(3)$} & \multicolumn{2}{|c|}{$(1)-(4)$} \\
\hline & & & & & \multicolumn{2}{|c|}{$(5)$} & \multicolumn{2}{|c|}{$(6)$} \\
\hline & 54.512 & 57.016 & 58.947 & 61.846 & $-4.435^{* * *}$ & -2.73 & $-7.334^{* * *}$ & -3.59 \\
\hline Outside director $(\mathrm{d})$ & 0.938 & 0.857 & 0.930 & 0.819 & 0.008 & 0.17 & $0.119^{*}$ & 1.74 \\
\hline Independent outside director (d) & 0.700 & 0.639 & 0.928 & 0.915 & $-0.228 * * *$ & -4.96 & $-0.215^{* * *}$ & -4.28 \\
\hline Current CEO (d) & 0.000 & 0.083 & 0.021 & 0.059 & -0.021 & -0.82 & -0.059 & -1.37 \\
\hline Current inside director (d) & 0.033 & 0.056 & 0.029 & 0.073 & 0.005 & 0.16 & -0.039 & -0.83 \\
\hline Current C-level exec. (d) & 0.167 & 0.167 & 0.088 & 0.097 & 0.078 & 1.53 & 0.069 & 1.29 \\
\hline Current VP-level exec. (d) & 0.133 & 0.056 & 0.068 & 0.031 & 0.065 & 1.44 & $0.103^{* * *}$ & 3.23 \\
\hline Connection to $\mathrm{CEO}(\mathrm{d})$ & 0.097 & 0.028 & 0.141 & 0.180 & -0.044 & -0.72 & -0.083 & -1.21 \\
\hline Education (score) & 2.875 & 2.762 & 2.853 & 2.779 & 0.022 & 0.13 & 0.096 & 0.52 \\
\hline Ivy League (d) & 0.156 & 0.310 & 0.256 & 0.261 & -0.100 & -1.31 & -0.105 & -1.34 \\
\hline \# different positions & 4.188 & 4.786 & 4.099 & 4.210 & 0.089 & 0.15 & -0.022 & -0.03 \\
\hline \# different firms & 3.188 & 3.452 & 4.135 & 4.192 & -0.947 & -1.50 & -1.004 & -1.37 \\
\hline \# different industries & 3.531 & 3.476 & 3.961 & 3.561 & -0.429 & -0.74 & -0.030 & -0.05 \\
\hline Industry experience (d) & 0.344 & 0.476 & 0.473 & 0.505 & -0.129 & -1.49 & $-0.162^{*}$ & -1.83 \\
\hline Director experience $(d)$ & 0.406 & 0.571 & 0.634 & 0.641 & $-0.228^{* * *}$ & -2.72 & $-0.235^{* * *}$ & -2.77 \\
\hline Outside director experience (d) & 0.406 & 0.548 & 0.617 & 0.598 & $-0.211^{* *}$ & -2.49 & $-0.192^{* *}$ & -2.21 \\
\hline Number of directors & 32 & 42 & 1,167 & 5,917 & \multicolumn{2}{|c|}{1,199} & \multicolumn{2}{|c|}{5,949} \\
\hline Number of outside directors & 30 & 36 & 1,085 & 4,846 & \multicolumn{2}{|c|}{1,115} & \multicolumn{2}{|c|}{4,876} \\
\hline Number of firms & 456 & 456 & 456 & 456 & \multicolumn{2}{|c|}{456} & \multicolumn{2}{|c|}{456} \\
\hline
\end{tabular}


Panel B: Newly appointed female directors vs. appointed male directors and newly appointed female vs. leaving female directors

\begin{tabular}{|c|c|c|c|c|c|c|c|c|}
\hline \multirow[b]{4}{*}{ Age (yrs) } & \multicolumn{2}{|c|}{ Newly appointed directors } & \multicolumn{2}{|c|}{ Leaving directors } & \multicolumn{4}{|c|}{ Differences } \\
\hline & \multirow{2}{*}{$\frac{\text { Female }}{(1)}$} & \multirow{2}{*}{$\begin{array}{c}\text { Male } \\
(2)\end{array}$} & \multirow{2}{*}{$\frac{\text { Female }}{(3)}$} & \multirow{2}{*}{$\begin{array}{c}\text { Male } \\
(4)\end{array}$} & \multicolumn{2}{|c|}{$(1)-(2)$} & \multicolumn{2}{|c|}{$(1)-(3)$} \\
\hline & & & & & \multicolumn{2}{|c|}{$(5)$} & \multicolumn{2}{|c|}{$(6)$} \\
\hline & 54.512 & 57.016 & 62.125 & 59.063 & -2.504 & -1.39 & $-7.613^{* *}$ & -2.11 \\
\hline Outside director $(\mathrm{d})$ & 0.938 & 0.857 & 0.800 & 0.857 & 0.080 & 1.10 & 0.138 & 1.03 \\
\hline Independent outside director (d) & 0.700 & 0.639 & 1.000 & 0.907 & 0.061 & 0.52 & -0.300 & -1.27 \\
\hline Current CEO (d) & 0.000 & 0.083 & 0.000 & 0.037 & -0.083 & -1.63 & 0.000 & 0.00 \\
\hline Current inside director (d) & 0.033 & 0.056 & 0.000 & 0.056 & -0.022 & -0.43 & 0.033 & 0.36 \\
\hline Current C-level exec. (d) & 0.167 & 0.167 & 0.250 & 0.056 & 0.000 & 0.00 & -0.083 & -0.40 \\
\hline Current VP-level exec. (d) & 0.133 & 0.056 & 0.000 & 0.000 & 0.078 & 1.09 & 0.133 & 0.76 \\
\hline Connection to CEO (d) & 0.097 & 0.028 & 0.250 & 0.224 & 0.069 & 1.18 & -0.153 & -0.89 \\
\hline Education (score) & 2.875 & 2.762 & 3.200 & 2.825 & 0.113 & 0.58 & -0.325 & -0.99 \\
\hline Ivy League (d) & 0.156 & 0.310 & 0.600 & 0.317 & -0.153 & -1.53 & $-0.444^{* *}$ & -2.35 \\
\hline \# different positions & 4.188 & 4.786 & 3.000 & 3.825 & -0.598 & -0.63 & 1.188 & 0.66 \\
\hline \# different firms & 3.188 & 3.452 & 5.800 & 3.746 & -0.265 & -0.39 & $-2.613^{*}$ & -1.78 \\
\hline \# different industries & 3.531 & 3.476 & 3.200 & 2.762 & 0.055 & 0.08 & 0.331 & 0.22 \\
\hline Industry experience (d) & 0.344 & 0.476 & 0.400 & 0.476 & -0.132 & -1.14 & -0.056 & -0.24 \\
\hline Director experience $(\mathrm{d})$ & 0.406 & 0.571 & 0.800 & 0.667 & -0.165 & -1.41 & -0.394 & -1.66 \\
\hline Outside director experience (d) & 0.406 & 0.548 & 0.800 & 0.635 & -0.141 & -1.20 & -0.394 & -1.66 \\
\hline Number of directors & 32 & 42 & 5 & 63 & \multicolumn{2}{|c|}{74} & \multicolumn{2}{|c|}{37} \\
\hline Number of outside directors & 30 & 36 & 4 & 54 & \multicolumn{2}{|c|}{66} & \multicolumn{2}{|c|}{34} \\
\hline Number of firms & 456 & 456 & 456 & 456 & \multicolumn{2}{|c|}{456} & \multicolumn{2}{|c|}{456} \\
\hline
\end{tabular}




\section{Appendix: Variable definitions}

This table reports variable definitions of all variables used in the paper as well as their data sources. Database mnemonics are in italics.

Panel A: Firm characteristics

\begin{tabular}{ll}
\hline Variable & Definition \\
\hline CA HQ (d) & Dummy variable equal to one if a firm is headquartered (state) in California as of September-end \\
& 2018 , zero otherwise. \\
& Abnormal return on day t, where October 1, 2018, marks the event date ( $\mathrm{t}=0$ ). Daily abnormal \\
& returns are calculated as the observed return minus a predicted return. Except if otherwise noted, \\
& the predicted return is estimated using a market model regression where daily returns (adjusted for \\
& distributions and stock splits) are regressed on daily value-weighted index returns over a 180 -day \\
& estimation window that ends six trading days prior to the event (September 21$)$ At least 90 daily \\
& observations with non-missing stock and index return data are required. Winsorized at the $1 \%$ and \\
& $99 \%$ level.
\end{tabular}

$\operatorname{CAR}\left(\mathrm{t}_{1}, \mathrm{t}_{2}\right)$

ROA

\section{Leverage}

Total assets

PPE / TA

R\&D / TA

Board size

Female directors $(\%)$

Female inside directors $(\%)$

Female outside directors $(\%)$

2021 requ. failed (d)

\# female directors missing

Shortfall (\%)
Cumulative abnormal return, estimated as the sum of daily (unwinsorized) abnormal returns (AR) from $t_{1}$ to $t_{2}$ where October 1, 2018 marks the event date. Winsorized at the 1\% and $99 \%$ level.

Operating income before depreciation scaled by total assets (oibdp / at), winsorized at the $1 \%$ and $99 \%$ level.

Long-term debt and debt in current liabilities scaled by total assets $((d l t t+d l c) / a t)$, winsorized at Compustat the $1 \%$ and $99 \%$ level.

Total assets $(a t)$.

Property, plant, and equipment scaled by total assets (ppent / at), winsorized at the $1 \%$ and $99 \%$ level.

Research and development expenses scaled by total assets (xrd / at). Set to zero if $x r d$ is missing in Compustat, winsorized at the $1 \%$ and $99 \%$ level.

Number of directors on the board.

Fraction of directors on the board that are female.

Number of female inside directors to all inside directors on the board.

Number of female outside directors to all outside directors on the board.

Dummy variable equal to one if a firm fails to comply with the 2021 female director requirements of Senate Bill No. 826, that is, a firm does not have three female directors if board size is six or more, two female directors if board size is five, and one female director if board size is four or less, zero otherwise.

Number of female directors necessary to fulfill the 2021 female director requirements of Senate Bill No. 826, that is, 3 minus the current number of female directors if board size is six or more, two minus the current number of female directors if board size is five, and 1 minus the current number of female directors if board size is four or less.

\# female directors missing scaled by board size.
Source

Compustat

Compustat

Compustat

Compustat

Compustat

Compustat

Compustat

BoardEx

BoardEx

BoardEx

BoardEx

BoardEx

BoardEx

BoardEx 
Largest size quintile (d)

Modified E-Index

Missing female directors in industry in $\mathrm{CA}$

$\%$ missing female directors

in industry in CA

$\%$ votes Democrats

\% votes Republican

Trump (d)

Tenure female directors
Dummy variable equal to one if a firm is in the highest Total asset quintile, zero otherwise.

Score variable that adds one for each of the following five provisions in place as of September 30 ,

2018: Existance of a poison pill, existance of a staggered board, existance of a supermajority vote requirement to amend the bylaws, existance of a supermajority vote requirement to amend the charter, existance of a supermajority vote requirement for mergers. We disregard golden parachutes as the sixth provision of Bebchuk, Cohen, and Ferrell's (2009) E-Index because it is not available in SharkRepellent.

Sum of \# female directors missing across all CA-headquartered firms in two-digit SIC code industry.

Sum of \# female directors missing across all CA-headquartered firms in two-digit SIC code industry scaled by the sum of \# female directors missing across all firms in two-digit SIC code industry.

Fraction of votes obtained by Democratic Party in 2016 Presidential Election in the state of a company's headquarter.

Fraction of votes obtained by Republican Party in 2016 Presidential Election in the state of a company's headquarter.

Dummy variable equal to one if the state of a company's headquarter was won by the Republican Party in the 2016 Presidential Election.

Mean tenure in years of all female directors on the board. Set to missing if firm has no female director.
Compustat

Shark-

Repellent

Compustat/

BoardEx

Compustat/

BoardEx

Politico

Politico

Politico

BoardEx 
Panel B: Director characteristics

\begin{tabular}{l} 
Variable \\
\hline Female (d) \\
Age (yrs) \\
Outside director (d) \\
Independent outside \\
director (d) \\
Current CEO (d)
\end{tabular}

Current inside director $(d)$

Current C-level exec. (d)

Current VP-level exec. (d)
Definition

Dummy variable equal to one if a director's gender (gender) is female, zero if male.

Years passed since the date of birth $(d o b)$. If only month and year of $d o b$ is available, we use the 15 th of a given month, if only the year of $d o b$ is available, we use July 1st of a given year.

Dummy variable equal to one if a director is an outside director (ned), zero if not.

Dummy variable equal to one if an outside director is independent (rolename), zero if not.

Dummy variable equal to one if an outside director serves as a CEO of another listed firm, 2018, and zero otherwise.

Dummy variable equal to one if an outside serves as an inside director of another listed firm, and zero otherwise.

Dummy variable equal to one if an outside serves as a C-level executive of another listed firm, and zero otherwise. C-level executives include titles such as Chief Executive Officer, Chief Financial Officer, Chief Operating Officer, etc.

Dummy variable equal to one if an outside director serves as a Vice President of another listed firm, and zero otherwise. VP executives include Vice Presidents and Senior Vice Presidents.

Dummy variable equal to one if a director either has an education, an employment, or an other activity connection to the CEO. An employment connection exists if a director has or had an overlapping work engagement with the CEO at another listed firm. An education connection exists if a director and the CEO are or were active (other rolename than "member") in the same social organization and zero otherwise. An education connection exists if a director graduated within one year of the CEO from the same university. For education connections, we disregard licenses (e.g., pilot license), leadership programs (e.g., Harvard's Advanced Management Program), certificates (e.g., CPA or CFA), and honorary degrees. For degrees of the director and the $\mathrm{CEO}$ we require information on the degree year and that both graduate with a degree from the respective program.

Score variable that equals one if a director's highest degree is below a Bachelor's degree, two if the highest degree is a Bachelor's degree, three if the highest degree is a Master's degree, four if the highest degree is a $\mathrm{PhD}$, and zero otherwise (Graham, Li, and Qiu, 2012). We disregard licenses (e.g., pilot license), leadership programs (e.g., Harvard's Advanced Management Program), certificates (e.g., CPA or CFA), and honorary degrees. We further require that a director graduates from a program with a degree, attending a program is not sufficient.

Ivy League (d) \# different positions \# different firms \# different industries
Dummy variable equal to one if a director graduated from an Ivy League school and zero otherwise. Number of different positions at listed firms a director has experience in outside of the sample firm. Number of different listed firms a director has experience in besides the sample firm.

Number of different four-digit SIC code industries a director has experience in outside of the sample firm's four-digit SIC industry.
Source

BoardEx

BoardEx

BoardEx

BoardEx

BoardEx

BoardEx

BoardEx

BoardEx

BoardEx

BoardEx

BoardEx

BoardEx

BoardEx

BoardEx/

CRSP 
Tenure (yrs)

Industry experience $(\mathrm{d})$

Director experience (d)

Outside director experience (d)
Years passed between a given measurement date and the date of the first board appointment at the sample firm.

Dummy variable equal to one if a director has experience at another listed firm that is active in the same two-digit SIC code industry as the sample firm and zero otherwise.

Dummy variable equal to one if a director has experience as a director of another listed firm and zero otherwise.

Dummy variable equal to one if a director has experience as an outside director of another listed firm and zero otherwise.
BoardEx

BoardEx/

CRSP

BoardEx

BoardEx 


\section{Table OA.1: Balancing tests}

This table reports differences in firm characteristics between California-headquartered firms (CA HQ $(d)=1)$ and non-California-headquartered US firms (CA HQ $(\mathrm{d})=0)$. The table reports means, medians, and the number of observations. The table also reports results from tests for differences in means and medians in firm characteristics between the two subsamples. The sample comprises all firms in Compustat with a data entry within one calendar year before September-end 2018, excluding utility and financial firms (SIC codes 4940-4949 and 6000-6999, respectively), firms with missing information on the state in which it is headquartered, firms headquartered outside the US, firms with negative book value of equity, firms with missing financial control variables, firms that only list American Depository Receipts, and firms without a listing on NYSE, AMEX, or NASDAQ. We also require at least 125 daily return observations during the 250-day estimation window that ends September 21 and complete return data for the entire five-day event window around the event date (October 1). Panel A shows balancing tests for the resulting sample. Panel B shows balancing tests for a sample in which we draw, for each firm headquartered in California, the three closest firms in terms of size that are active in the same two-digit SIC code industry. While the same firm may serve as a matched control firm to more than one California-headquartered firm, every control firm is included only once in our sample. All financial ratios are winsorized at the 1st and 99th percentiles. Detailed variable definitions are in the Appendix. *, **, and ${ }^{* * *}$, indicate statistical significance at the $10 \%, 5 \%$, and $1 \%$ level, respectively.

Panel A: All non-CA headquartered firms

\begin{tabular}{|c|c|c|c|c|c|c|c|c|c|c|}
\hline & \multicolumn{3}{|c|}{$\mathrm{CA} \mathrm{HQ}(\mathrm{d})=1$} & \multicolumn{3}{|c|}{$\mathrm{CA} \mathrm{HQ}(\mathrm{d})=0$} & \multicolumn{4}{|c|}{ Differences } \\
\hline & Mean & Median & $\mathrm{N}$ & Mean & Median & $\mathrm{N}$ & Mean & t-value & Median & z-value \\
\hline $\mathrm{ROA}$ & -0.128 & 0.016 & 456 & 0.007 & 0.092 & 2,006 & $-0.135^{* * *}$ & -8.41 & $-0.076^{* * *}$ & -8.77 \\
\hline Leverage & 0.168 & 0.115 & 456 & 0.233 & 0.219 & 2,006 & $-0.065^{* * *}$ & -6.41 & $-0.104^{* * *}$ & -6.59 \\
\hline Total assets & $5,484.968$ & 384.670 & 456 & $6,547.411$ & 861.613 & 2,006 & $-1,062.442$ & -0.73 & $-476.943^{* * *}$ & -6.32 \\
\hline $\mathrm{PPE} / \mathrm{TA}$ & 0.120 & 0.067 & 456 & 0.243 & 0.143 & 2,006 & $-0.123^{* * *}$ & -9.96 & $-0.077^{* * *}$ & -10.40 \\
\hline $\mathrm{R} \& \mathrm{D} / \mathrm{TA}$ & 0.166 & 0.100 & 456 & 0.065 & 0.001 & 2,006 & $0.101^{* * *}$ & 12.57 & $0.099^{* * *}$ & 15.59 \\
\hline Board size & 7.666 & 8.000 & 455 & 8.213 & 8.000 & 2,000 & $-0.547 * * *$ & -4.91 & $-0.000 * * *$ & -4.80 \\
\hline Female directors $(\%)$ & 0.146 & 0.143 & 455 & 0.155 & 0.143 & 2,000 & -0.009 & -1.30 & -0.000 & -1.25 \\
\hline 2021 requ. failed (d) & 0.888 & 1.000 & 455 & 0.829 & 1.000 & 2,000 & $0.059^{* * *}$ & 3.12 & $0.000 * * *$ & 3.12 \\
\hline \# missing female directors & 1.644 & 2.000 & 455 & 1.495 & 2.000 & 2,000 & $0.149^{* *}$ & 2.52 & $0.000^{* *}$ & 2.09 \\
\hline Shortfall $(\%)$ & 0.235 & 0.250 & 455 & 0.210 & 0.222 & 2,000 & $0.026^{* * *}$ & 3.05 & $0.028 * * *$ & 3.02 \\
\hline
\end{tabular}


Panel B: Same two-digit SIC industry, closest 3 TA matches

\begin{tabular}{|c|c|c|c|c|c|c|c|c|c|c|}
\hline & \multicolumn{3}{|c|}{$\mathrm{CA} \mathrm{HQ}(\mathrm{d})=1$} & \multicolumn{3}{|c|}{$\mathrm{CA} \mathrm{HQ}(\mathrm{d})=0$} & \multicolumn{4}{|c|}{ Differences } \\
\hline & Mean & Median & $\mathrm{N}$ & Mean & Median & $\mathrm{N}$ & Mean & t-value & Median & z-value \\
\hline $\mathrm{ROA}$ & -0.132 & 0.016 & 456 & -0.060 & 0.069 & 777 & $-0.071^{* * *}$ & -3.26 & $-0.053^{* * *}$ & -3.96 \\
\hline Total assets & $5,484.968$ & 384.670 & 456 & $3,810.083$ & 376.335 & 777 & $1,674.885$ & 1.28 & 8.335 & 0.18 \\
\hline $\mathrm{PPE} / \mathrm{TA}$ & 0.120 & 0.067 & 456 & 0.151 & 0.090 & 777 & $-0.031^{* * *}$ & -3.07 & $-0.024^{* * *}$ & -3.31 \\
\hline $\mathrm{R} \& \mathrm{D} / \mathrm{TA}$ & 0.169 & 0.100 & 456 & 0.109 & 0.027 & 777 & $0.06^{* * *}$ & 5.26 & $0.073^{* * *}$ & 7.58 \\
\hline Female directors (\%) & 0.146 & 0.143 & 455 & 0.147 & 0.143 & 775 & -0.000 & -0.07 & -0.000 & -0.10 \\
\hline 2021 requ. failed $(\mathrm{d})$ & 0.888 & 1.000 & 455 & 0.867 & 1.000 & 775 & 0.021 & 1.06 & 0.000 & 1.06 \\
\hline \# missing female directors & 1.644 & 2.000 & 455 & 1.590 & 2.000 & 775 & 0.054 & 0.87 & 0.000 & 0.68 \\
\hline Shortfall $(\%)$ & 0.235 & 0.250 & 455 & 0.228 & 0.250 & 775 & 0.008 & 0.83 & 0.000 & 0.69 \\
\hline
\end{tabular}




\section{Table OA.2: Univariate return differences}

This table reports differences in abnormal returns between California-headquartered firms and US nonCalifornia-headquartered firms around the quota adoption announcement. We report results from t-tests against zero for different abnormal return measures for the subsample of firms headquartered in California (CA HQ (d) =1) and for the subsample of firms headquartered in any other US state but California (CA HQ $(d)=0)$. Daily abnormal returns are computed as the observed return minus the predicted return from a market model regression estimated over a 250-day estimation window that ends on Friday, September 21. As a proxy for the market return, we use the return of a self-computed, value-weighted market index consisting of all sample firms. The sample comprises all firms in Compustat with a data entry within one calendar year before September-end 2018, excluding utility and financial firms (SIC codes 4940-4949 and 6000-6999, respectively), firms with missing information on the state in which it is headquartered, firms headquartered outside the US, firms with negative book value of equity, firms with missing financial control variables, firms that only list American Depository Receipts, and firms without a listing on NYSE, AMEX, or NASDAQ. We also require at least 125 daily return observations during the 250-day estimation window and complete return data for the entire five-day event window around the event date (October 1). Panel A reports results from comparing abnormal return measures of California-headquartered firms to a sample of matched non-California-headquartered firms. The matched sample is obtained by choosing for each California-headquartered sample firm the three closest firms in terms of size that are active in the same two-digit SIC code industry. While the same firm may serve as a matched control firm to more than one California-headquartered firm, every control firm is included only once in our sample. Panel B reports results from comparing abnormal return measures of California-headquartered firms to all US non-California-headquartered firms. All abnormal return measures are winsorized at the 1st and 99th percentiles. Detailed variable definitions are in the Appendix. ${ }^{*},{ }^{* *}$, and ${ }^{* * *}$, indicate statistical significance at the $10 \%, 5 \%$, and $1 \%$ level, respectively.

Panel A: Same two-digit SIC industry, closest 3 TA matches

\begin{tabular}{|c|c|c|c|c|c|c|c|c|}
\hline & \multicolumn{3}{|c|}{$\mathrm{CA} \mathrm{HQ}(\mathrm{d})=1$} & \multicolumn{3}{|c|}{$\mathrm{CA} H Q(\mathrm{~d})=0$} & \multicolumn{2}{|c|}{ Differences } \\
\hline & Mean & t-value & $\mathrm{N}$ & Mean & $\mathrm{t}$-value & $\mathrm{N}$ & Mean & t-value \\
\hline AR (0) & $-1.45 \% * * *$ & -9.74 & 456 & $-0.98 \% * * *$ & -7.86 & 777 & $-0.47 \% * *$ & -2.37 \\
\hline $\mathrm{AR}(1)$ & $-1.07 \% * * *$ & -7.63 & 456 & $-0.72 \% * * *$ & -6.31 & 777 & $-0.35 \% *$ & -1.90 \\
\hline CAR $(0,1)$ & $-2.48 \% * * *$ & -11.63 & 456 & $-1.73 \% * * *$ & -10.11 & 777 & $-0.75 \% * * *$ & -2.71 \\
\hline $\operatorname{CAR}(-1,1)$ & $-2.64 \% * * *$ & -9.99 & 456 & $-1.80 \% * * *$ & -8.55 & 777 & $-0.84 \% * *$ & -2.45 \\
\hline CAR $(0,2)$ & $-1.87 \% * * *$ & -7.42 & 456 & $-0.87 \% * * *$ & -4.00 & 777 & $-1.01 \% * * *$ & -2.93 \\
\hline CAR $(-2,2)$ & $-2.40 \% * * *$ & -7.03 & 456 & $-1.21 \% * * *$ & -4.53 & 777 & $-1.19 \% * * *$ & -2.73 \\
\hline
\end{tabular}

Panel B: All non-CA headquarted firms as control firms

\begin{tabular}{|c|c|c|c|c|c|c|c|c|}
\hline & \multicolumn{3}{|c|}{$\mathrm{CA} \mathrm{HQ}(\mathrm{d})=1$} & \multicolumn{3}{|c|}{$\mathrm{CA} \mathrm{HQ}(\mathrm{d})=0$} & \multicolumn{2}{|c|}{ Differences } \\
\hline & Mean & t-value & $\mathrm{N}$ & Mean & $\mathrm{t}$-value & $\mathrm{N}$ & Mean & t-value \\
\hline AR (0) & $-1.45 \% * * *$ & -10.01 & 456 & $-0.87 \% * * *$ & -13.75 & 2,006 & $-0.58 \% * * *$ & -3.90 \\
\hline AR (1) & $-1.09 \% * * *$ & -8.07 & 456 & $-0.62 \% * * *$ & -10.56 & 2,006 & $-0.47 \% * * *$ & -3.37 \\
\hline CAR $(0,1)$ & $-2.48 \% * * *$ & -11.77 & 456 & $-1.48 \% * * *$ & -16.18 & 2,006 & $-1.01 \% * * *$ & -4.65 \\
\hline $\operatorname{CAR}(-1,1)$ & $-2.61 \% * * *$ & -10.32 & 456 & $-1.49 \% * * *$ & -14.03 & 2,006 & $-1.12 \% * * *$ & -4.44 \\
\hline CAR $(0,2)$ & $-1.88 \% * * *$ & -7.55 & 456 & $-0.77 \% * * *$ & -6.96 & 2,006 & $-1.11 \% * * *$ & -4.24 \\
\hline CAR $(-2,2)$ & $-2.32 \% * * *$ & -7.27 & 456 & $-1.06 \% * * *$ & -7.85 & 2,006 & $-1.26 \% * * *$ & -3.93 \\
\hline
\end{tabular}

